\title{
On the interest of positive degree day models for mass balance modeling in the inner tropics
}

L. Maisincho ${ }^{1,2}$, V. Favier ${ }^{3}$, P. Wagnon ${ }^{2,4}$, R. Basantes Serrano ${ }^{2,3}$, B. Francou ${ }^{2}$, M. Villacis ${ }^{5}$, A. Rabatel ${ }^{3}$, L. Mourre ${ }^{2}$, V. Jomelli ${ }^{6}$, and B. Cáceres ${ }^{1}$

${ }^{1}$ INAMHI, Instituto Nacional de Meteorología e Hidrología, Iñaquito N36-14 y Corea, Quito, Ecuador

${ }^{2}$ Univ. Grenoble Alpes, CNRS, IRD, LTHE (UMR5564), 38000 Grenoble, France

${ }^{3}$ Univ. Grenoble Alpes, CNRS LGGE (UMR5183), 38000 Grenoble, France

${ }^{4}$ ICIMOD, G.P.O. Box 3226, Kathmandu, Nepal

${ }^{5}$ EPN, Escuela Politécnica Nacional, Ladrón de Guevara E11-253, Quito, Ecuador

${ }^{6}$ LGP, Université Paris 1 Panthéon-Sorbonne-CNRS, 92195 Meudon, France

Received: 1 April 2014 - Accepted: 6 May 2014 - Published: 23 May 2014

Correspondence to: L. Maisincho (Imaisincho@yahoo.com)

Published by Copernicus Publications on behalf of the European Geosciences Union.

\section{On the interest of positive degree day \\ models for mass \\ balance modeling in \\ the inner tropics \\ L. Maisincho et al.}

Title Page

Abstract

Introduction

Conclusions

References

Tables

Figures

14

4

Back

DI

$>$

\section{Close}

Full Screen / Esc

Printer-friendly Version

Interactive Discussion 


\section{Abstract}

A positive degree-day (PDD) model was tested on Antizana Glacier $15 \alpha\left(0.28 \mathrm{~km}^{2}\right.$; $0^{\circ} 28^{\prime} \mathrm{S}, 78^{\circ} 09^{\prime} \mathrm{W}$ ) to assess to what extent this approach is suitable for studying glacier mass balance in the inner tropics. Cumulative positive temperatures were compared with field measurements of melting amount and with surface energy balance computations. A significant link was revealed when a distinction was made between the snow and ice comprising the glacier surface. Significant correlations allowed degree-day factors to be retrieved for snow, and clean and dirty ice. The relationship between melt amount and temperature was mainly explained by the role of net shortwave radiation in both melting and in the variations in the temperature of the surface layer. However, this relationship disappeared from June to October (Period 1), because high wind speeds and low humidity cause highly negative turbulent latent heat fluxes. However, this had little impact on the computed total amount of melting at the annual time scale because temperatures are low and melting is generally limited during Period 1. At the daily time scale, melting starts when daily temperature means are still negative, because around noon incoming shortwave radiation is very high, and compensates for energy losses when the air is cold. The PDD model was applied to the 2000-2008 period using meteorological inputs measured on the glacier foreland. Results were compared to the glacier-wide mass balances measured in the field and were good, even though the melting factor should be adapted to the glacier surface state and may vary with time. Finally, the model was forced with precipitation and temperature data from the remote Izobamba station and NCEP-NCAR reanalysis data, also giving good results and showing that temperature variations are homogenous at the regional scale, meaning glacier mass balances can be modelled over large areas.
On the interest of positive degree day models for mass balance modeling in the inner tropics

L. Maisincho et al.

Title Page

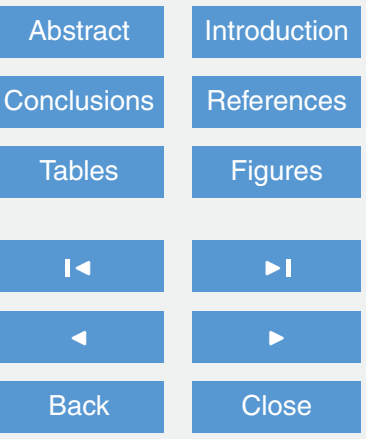

Full Screen / Esc

Printer-friendly Version

Interactive Discussion 


\section{Introduction}

In recent decades, hydro-glacio-meteorological monitoring programs have been conducted to improve our understanding of current climate change in the high elevation Andes and to more accurately estimate its impact on ice-covered areas (e.g., Has-

5 tenrath, 1981; Hastenrath and Kruss, 1992; Francou et al., 1995, 2000; Kaser and Osmaston, 2002; Rabatel et al., 2013). In Ecuador, glaciological studies began on Antizana Glacier $15 \alpha$ in 1994 (Francou et al., 2000; Favier et al., 2004a). Ecuadorian glaciers respond rapidly to climate change, in particular to temperature variations. The comparison of glacier extents using photogrammetric information available since 1956

10 (Francou et al., 2000; Basantes Serrano et al., 2014) with local variations in temperature suggests that local warming of the atmosphere (about $0.2^{\circ} \mathrm{C}$ decade ${ }^{-1}$, Vuille et al., 2000) has played an important role in glacier retreat since the 1950s (Francou et al., 2000), with direct consequences for the local water supply to Quito (e.g., Favier et al., 2008; Villacis, 2008). Temperature changes are generally assumed to be the 15 main parameter involved in glacier retreat in the Ecuadorian Andes because the $0^{\circ} \mathrm{C}$ level oscillates continuously around the ablation zone average altitude throughout the year (Kaser, 2001; Favier et al., 2004a, b; Francou et al., 2004; Rabatel et al., 2013). Slight changes in temperature directly modify the ablation processes at the glacier surface due to the precipitation phase and its impact on the surface albedo (e.g., Francou et al., 2004; Favier et al., 2004a). For instance, El Nino events lead to the rise of the $0{ }^{\circ} \mathrm{C}$ level, and therewith have major consequences for the precipitation phase over the glacier, leading to high melting rates (e.g., Francou et al., 2004; Favier et al., 2004b). However, a direct link between higher temperature and increased ablation has never been clearly demonstrated. Because the warming expected in the high elevation Andes 25 in the 21st century (between 4 and $5^{\circ} \mathrm{C}$ ) (Bradley et al., 2006; Vuille et al., 2008; Urrutia and Vuille, 2009) will likely be greater than estimated warming since the early Holocene (Jomelli et al., 2011), if this link does exist, glacial retreat could be dramatic in the coming decades. Understanding and modeling glacial retreat under local warming is thus
On the interest of positive degree day models for mass balance modeling in the inner tropics

L. Maisincho et al.

\section{Title Page}

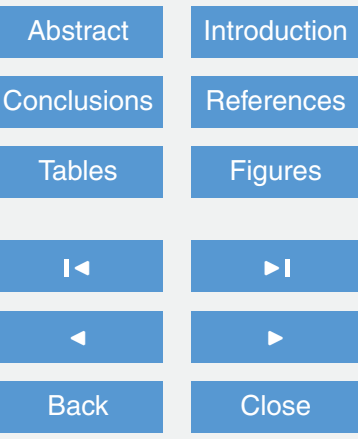

Full Screen / Esc

Printer-friendly Version

Interactive Discussion 
crucial, but first, we need to show that empirical approaches based on the relationship between temperature and melting are appropriate.

Positive degree-day (PDD) models (e.g., Braithwaite, 1995; Hock, 2003) have been widely used in tropical areas to study past glacier length fluctuations (e.g., Hostettler 5 and Clark, 2000; Blard et al., 2007; Jomelli et al., 2011). The physical basis for the PDD model is that net longwave radiation, sensible heat flux, and to a certain extent, the latent heat flux over a melting ice surface are significantly correlated with air temperature (Ohmura, 2001). The PDD model should also be applied in climatic zones with a welldefined annual air temperature cycle (Ohmura, 2001), i.e. outside the tropics. Sicart et al. (2008) suggested that PDD models should be used with caution even in the tropics because temperature is not directly linked to the main local ablation processes. These authors argued that the shortwave radiation budget is the main process that determines the annual surface mass balance (Wagnon et al., 1999; Favier et al., 2004a, b; Sicart et al., 2008), and that the turbulent sensible heat flux and incoming longwave 15 radiation are generally of less importance, with a low correlation between temperature and melting processes. However, the study by Sicart et al. (2008) in the Andes was mainly based on data collected on Zongo Glacier, which is in the outer tropics (e.g., Kaser, 2001), whereas the inner tropics were only briefly analyzed. Sicart et al. (2008) used a 6 month dataset (September to February), but not a full annual cycle, whereas, unlike in the outer tropics, in Ecuador, a melting season is hard to define (e.g., Kaser and Osmaston, 2002). Moreover, in their correlation analysis Sicart et al. did not distinguish between snow and ice, whereas degree-day factors (DDF) are expected to be very different for the two surface states (e.g., Braithwaite, 1995). Finally, their analysis did not include direct field measurements of specific snow and ice melt to assess melt factors. Therefore, their conclusions concerning the inner tropics cannot be considered definitive and a specific focus there is still necessary.

In this study, we tested a PDD model on Antizana Glacier $15 \alpha\left(0.28 \mathrm{~km}^{2} ; 0^{\circ} 28^{\prime} \mathrm{S}\right.$, $78^{\circ} 09^{\prime} \mathrm{W}$ ) to judge whether PDD models can reasonably assess local glacier melting in the inner tropics. We were able to use direct melting measurements performed in

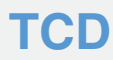

8, 2637-2684, 2014

On the interest of positive degree day models for mass balance modeling in the inner tropics

L. Maisincho et al.

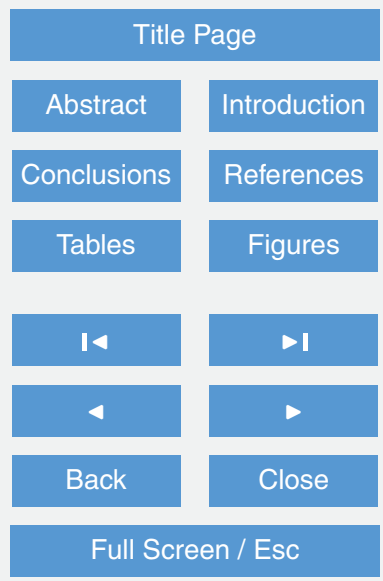

Printer-friendly Version

Interactive Discussion 
the field in 2002-2003 (Favier et al., 2004a) to analyze the capability of PDD models to accurately reproduce measured melting values. We also used the computed melting values from energy balance calculations by Favier et al. (2004a) and surface mass balance and equilibrium-line altitude (ELA) data from the GLACIOCLIM observa5 tory (http://www-lgge.ujf-grenoble.fr/ServiceObs/). We compared the distributed PDD model results with continuous snowline observations obtained with an automatic camera since 2004 to check whether this variable was correctly reproduced. Finally, a critical analysis of the sensitivity and limitations of the model was performed.

The paper is organized as follows: in Sect. 2, we provide a description of the regional 10 calibrate PDD model parameters using local melting measurements, and apply the model using meteorological datasets from different sources (from a local and a remote meteorological station, and then from reanalysis data). In Sect. 5, we describe model sensitivity. In Sect. 6, we discuss our results and examine when and how the PDD

\section{Study site, climatic setting and associated glaciological processes}

Antizana stratovolcano is one of the main ice covered summits in the Cordillera Oriental of Ecuador (Fig. 1). The last glacier inventory performed in 2006 showed that glaciers extended over a surface area of $12.2 \mathrm{~km}^{2}$ (Cáceres et al., 2006) distributed over 17 glacier tongues (Hastenrath, 1981). Glaciological and hydrological studies in the area began in 1994 on Antizana Glacier $15 \alpha$. This glacier is located on the north-western side of the volcano and is a reference site for long-term observations (Francou et al., 2000, 2004; Favier et al., 2004a, 2008; Rabatel et al., 2013). The surface of the glacier presently extends from $5700 \mathrm{~m}$ a.s.I. down to $4850 \mathrm{~m}$ a.s.l.

25 The study area belongs to the inner tropics, which are characterized by low temperature and moisture seasonality (e.g. Favier et al., 2004). The low latitude location yields diurnal temperature variations exceeding the seasonal variations of daily mean

On the interest of positive degree day models for mass balance modeling in the inner tropics

L. Maisincho et al.

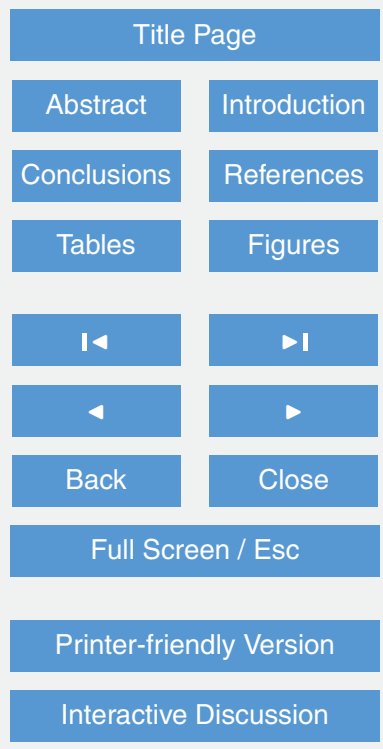


temperatures over one year. The annual precipitation recorded at $4550 \mathrm{~m}$ a.s.I. in the catchment of Antizana 15 Glacier ranged from 800 to $1300 \mathrm{~mm} \mathrm{a}^{-1}$ between 2000 and 2008. Precipitation is significant throughout the year; monthly variations showed two slight maxima in April and October, while slight minima appeared in July-August and 5 December (Favier et al., 2004a). As a consequence of these peculiar climatic settings, accumulation and ablation occur simultaneously and continuously. The mean $0^{\circ} \mathrm{C}$ level is generally around $4950-5000 \mathrm{~m}$ a.s.l., i.e. within the ablation zone. However, this value shows large interannual variability. Consequently, liquid and solid precipitation is frequent in the ablation area, and glaciological processes indirectly depend on temperature, because temperature directly controls the precipitation phase, and hence temperature acts on surface albedo (Favier et al., 2004a). On the other hand, during the period 2000-2008, wind velocity showed pronounced seasonal variations, with intense easterly winds generally occurring between June and October (hereafter referred to as Period 1, while Period 2 refers to the period from November to May of the 15 following year), which were associated with marked mass and energy losses through sublimation (Favier et al., 2004a).

Finally, most local climate variability is closely linked to the El Niño-Southern Oscillation (ENSO). There is a three month delay in the local response of the atmosphere to the ENSO signal. ENSO warm phases (EI Niño) are associated with local warming and a precipitation deficit leading to highly negative mass balances (Francou et al., 2004; Favier et al., 2008). Conversely, La Niña phases are colder and more humid, which results in more balanced or even positive mass budgets. Surface energy balance studies showed that these variations are closely linked with variations in albedo that mirror changes in the precipitation phase at the glacier surface due to variations in

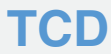

8, 2637-2684, 2014

On the interest of positive degree day models for mass balance modeling in

the inner tropics

L. Maisincho et al.

Title Page
Abstract

Conclusions

Tables

14

4

Back
Introduction

References

Figures

DI

$\triangleright$

Close
Full Screen / Esc

Printer-friendly Version

Interactive Discussion 


\section{Methods and data}

\subsection{The positive degree-day model}

In this paper, we test a simple PDD model that allows calculation of daily snow or ice melt $a_{j}(z)$ (in $\mathrm{mm}$ w.e.) at a given elevation $z$ (in $\mathrm{m}$ a.s.l.), and at time step $j$ (in days)

5 (Braithwaite, 1995; Hock, 2003):

$a_{j}(z)=-F\left(T_{j}\left(z_{\text {ref }}\right)+\operatorname{LR}\left(z-z_{\text {ref }}\right)-T_{\text {threshold }}\right)$ if $T_{j}\left(z_{\text {ref }}\right)+\mathrm{LR}\left(z-z_{\text {ref }}\right)>T_{\text {threshold }}$,

$a_{j}(z)=0$ if $T_{j}\left(z_{\text {ref }}\right)+\operatorname{LR}\left(z-z_{\text {ref }}\right) \leq T_{\text {threshold }}$,

where $F$ is the degree-day factor (DDF, in mm.w.e. $\mathrm{K}^{-1} \mathrm{~d}^{-1}$ ), $T_{j}(z)$ (in ${ }^{\circ} \mathrm{C}$ ) is the mean daily temperature, $z_{\text {ref }}=4900 \mathrm{~m}$ a.s.l. and $z$ (in $\mathrm{m}$ a.s.l.) are the reference elevation and the given elevation respectively, $T_{\text {threshold }}\left({ }^{\circ}{ }^{\circ} \mathrm{C}\right.$ ) is a threshold temperature above which melting begins, and $L R$ is the lapse rate in the atmosphere (in ${ }^{\circ} \mathrm{C} \mathrm{m}^{-1}$, hereafter expressed in ${ }^{\circ} \mathrm{C} \mathrm{km}^{-1}$ ). The PDD model generally assumes that $T_{\text {threshold }}=0{ }^{\circ} \mathrm{C}$. However, during short periods in the daytime, melting may occur when a negative daily mean is 15 observed (e.g. Van den Broeke et al., 2010). To avoid this problem, and as recommended in several studies (e.g. Van den Broeke et al., 2010), the model was first applied using cumulative amounts of positive temperature for each day, computed using hourly temperature values. However, because hourly temperatures are rarely available in long-term meteorological observations, we also applied the PDD model using daily 20 mean temperature values, in this case assuming a negative $T_{\text {threshold }}=-1.9^{\circ} \mathrm{C}$ (see Sect. 4.2).

The model can be run using different DDF values depending on the presence or absence of snow at the glacier surface at the previous time step, where $S_{j-1}(z)$ is the amount of snow in mm.w.e. at the time step $j-1$ :

${ }_{25} F=F_{\text {snow }}$ if $S_{j-1}(z)>0$ (in mm.w.e. $\mathrm{K}^{-1} \mathrm{~d}^{-1}$ )

$F=F_{\text {ice }}$ if $S_{j-1}(z)=0$ (in mm.w.e. $\mathrm{K}^{-1} \mathrm{~d}^{-1}$ ).

On the interest of positive degree day models for mass balance modeling in

the inner tropics

L. Maisincho et al.

Title Page

Abstract Introduction

Conclusions

References

Tables

Figures

14

DI

4

Back

Full Screen / Esc

Printer-friendly Version

Interactive Discussion 
Snow cover is the difference between ablation and snow accumulation at a given elevation $z$. Solid precipitation is assumed if the air temperature is below a threshold ( $T_{\text {snow/rain }}=1^{\circ} \mathrm{C}$, Azam et al., 2014), otherwise solid precipitation is zero. This threshold was obtained from field measurements and direct observations of the precipitation 5 phase in the Andes, which suggested that, below this temperature, more than $70 \%$ of precipitation is solid (e.g., L'Hôte et al., 2005). We assumed that total precipitation is constant with elevation. Temperature at a specific elevation is computed assuming a constant lapse rate $(\mathrm{LR})$ between the reference elevation $z_{\text {ref }}$, where meteorological data are available, and a given elevation $z$. A value of $L R=-6.5^{\circ} \mathrm{C} \mathrm{km}^{-1}$ (e.g., Rojas, 10 2006) is generally assumed in the free atmosphere. However, half-hourly field temperature measurements performed in artificially ventilated shelters at different elevations on Antizana Glacier 12 ( $2 \mathrm{~km}$ south of the Antizana Glacier $15 \alpha)$ suggested a mean lapse rate of $-8.0^{\circ} \mathrm{C} \mathrm{km}^{-1}$ (standard deviation of $3.0^{\circ} \mathrm{C} \mathrm{km}^{-1}$ for 18685 values) (data not shown). This vertical temperature gradient is higher than the humid adiabatic gra5 dient because Glacier 12 and 15 are located on the leeward side of the volcano, where there is a strong foehn effect that acts to steepen the vertical temperature gradient (e.g., Favier et al., 2004a). We use the latter value in the present paper, and a model sensitivity test against this parameter is presented in Sect. 5.

The elevation of the snowline $z_{\mathrm{SL}, j}$ was estimated using the model and compared 20 with field observations. The modeled snowline is the level at which the snow accumulation given by the model becomes positive. Finally, in the model, the ELA is the altitude at which the annual surface mass balance $b_{j}(z)$ is zero.

\subsection{Surface energy balance computation}

Daily ablation from the PDD model was compared with surface energy balance values 25 given by Favier et al. $(2004 \mathrm{a}, \mathrm{b})$. The energy stored in the top layers of the glacier $\Delta Q$ was calculated as (fluxes toward the surface are positive) (e.g., Oke, 1987; Favier et al.,

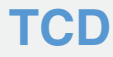

8, 2637-2684, 2014

On the interest of positive degree day models for mass balance modeling in

the inner tropics

L. Maisincho et al.

\section{Title Page}

Abstract

Conclusions

Tables

14

4

Back

Full Screen / Esc

Printer-friendly Version

Interactive Discussion 
2011):

$\Delta Q=S \downarrow(1-\alpha)+L \downarrow+L \uparrow+H+$ LE (in $\mathrm{W} \mathrm{m}^{-2}$ ).

Where, $S \downarrow$ is incident short-wave radiation, $\alpha$ is the albedo, $L \downarrow$ and $L \uparrow$ are incom5 ing and outgoing long-wave radiation, respectively, and $H$ and LE are turbulent sensible and latent heat fluxes, respectively. Conduction into the ice/snow or heat supplied by precipitation was ignored. When the surface temperature is at melting point, $\Delta Q$ represents the energy available for melt. The radiative fluxes were measured locally at 4900 m a.s.I. on Antizana $15 \alpha$ with a CNR1 Kipp\&Zonen net radiometer. Turbu-

10 lent fluxes were computed using the bulk aerodynamic approach assuming roughness lengths obtained through measurements of sublimation in the field. Temperature and humidity were measured using an artificially ventilated HMP45 Vaisala sensor and wind speed was measured using a Young 05103 anemometer. See Favier et al. (2004a) for details.

\subsection{Data}

\subsubsection{Meteorological data}

In this paper, we use data from four meteorological stations (Table 2) and two tipping bucket rain gauges (Table 1). The reference temperature used in our calculation is the value measured on the glacier at $4900 \mathrm{~m}$ a.s.l. The data and periods used in this paper (Table 3) are the following:

1. meteorological datasets recorded by the $\mathrm{AWS}_{\mathrm{G} 1}$ (Fig. 1) automatic weather station (AWS, hereafter referred to as $\mathrm{AWS}_{\mathrm{G} 1}, 4900$ m a.s.I.) between 1999 to 2004. The subindex $\mathrm{G} 1$ in $A W S_{\mathrm{G} 1}$ means glacier. The sensors installed on the $A W S_{\mathrm{G} 1}$ and the available data are the same as described in Favier et al. (2004a, b). Table 1 summarizes the observed variables and sensor characteristics for the period from 14 March 2002 to 31 March 2003. Data were used to compute the full surface energy balance i.e. for 376 days, except between 2 and 6 May 2002 due to

On the interest of positive degree day models for mass balance modeling in

the inner tropics

L. Maisincho et al.

Title Page

Abstract Introduction

Conclusions References

Tables Figures

14 4

Back

$\Delta 1$

$\triangleright$

Close

Printer-friendly Version

Interactive Discussion 
data gaps. The data are $30 \mathrm{~min}$ averages of measurements made at $15 \mathrm{~s}$ intervals. The $\mathrm{AWS}_{\mathrm{G} 1}$ thermometer was placed $2 \mathrm{~m}$ above the glacier surface in an artificially ventilated shelter.

2. In 2005 , the station was moved and located a few hundred meters away, at the same elevation ( $4900 \mathrm{~m}$ a.s.I.), on the lateral moraine of the glacier. Hereafter, the station is called $A W S_{M}$. The subindex $M$ in $A W S_{M}$ refers to the moraine. The sensors installed at this weather station were the same as those installed at the $\mathrm{AWS}_{\mathrm{G} 1}$ station.

3. We also used temperature measured with another ventilated thermometer installed on the glacier to obtain a continuous time series (Table 2). Data from another AWS were used from 2002 to 2008. This second AWS (hereafter referred to as $A_{W} S_{G 2}$ (Fig. 1)) was originally installed a few dozen meters away from the $\mathrm{AWS}_{\mathrm{G} 1}$ station, but was moved in 2003 and re-installed at $5000 \mathrm{~m}$ a.s.l. The $\mathrm{AWS}_{\mathrm{G} 2}$ was moved to the vicinity of glacier 12 in 2006 . For that reason, temperature data recorded in 2006 are not used in this paper. Finally, the $\mathrm{AWS}_{\mathrm{G} 2}$ was moved back to 4900 ma.s.l. on glacier 15 in 2007 . The daily temperature data recorded at $A W S_{G_{1}}$ and $A W S_{G 2}$ were significantly correlated in 2003 and 2004 (Table 2) and the regression equations were used to fill the data gaps at station $\mathrm{AWS}_{\mathrm{G} 1}$ between 2002 and 2004 (14\% of 1096 days). In 2005, 2007 and 2008, data from $\mathrm{AWS}_{\mathrm{G} 2}$ were used to compute the PDD, and data gaps (21\% of 1461 days) were filled with data from the $\mathrm{AWS}_{\mathrm{M}}$ because correlations between the two stations were significant (Table 2).

4. From 2000 to 2008 , daily temperature values measured at 4785 ma.s.l. with a HOBOPro sensor located in a Stevenson screen type B shelter (referred to as $\mathrm{HOBO}$ in Fig. 1 and Table 2) were also used to fill the remaining data gaps at $\mathrm{AWS}_{\mathrm{G1}}$ and $\mathrm{AWS}_{\mathrm{G} 2}$ (Table 2). Indeed, the correlations between daily temperature at $A W S_{G 1}$ and $A W S_{G 2}$ and the HOBOPro data in the same periods of measurements were significant (Table 2). These data allowed us to obtain 2646

On the interest of positive degree day models for mass balance modeling in the inner tropics

L. Maisincho et al.

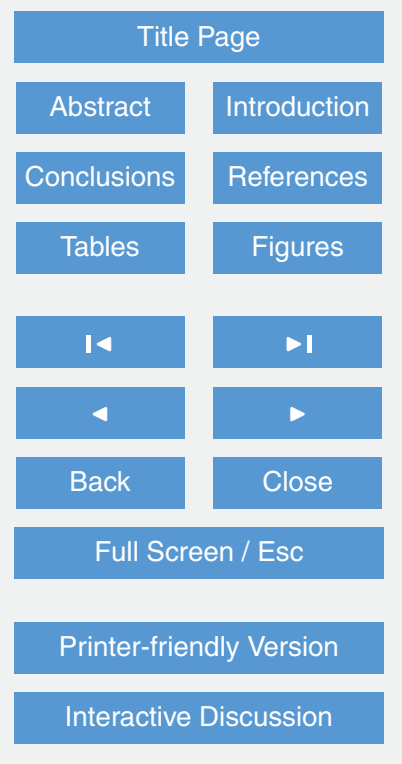


a continuous and homogeneous temperature dataset between 2000 and 2008 at $4900 \mathrm{~m}$ a.s.l.

5. Daily precipitation values from 2000 to 2008 came from an automatic tipping bucket HOBO rain gauge referred to as P4 (Fig. 1) located on the moorland (páramo) at 4550 ma.s.I. During this period, total data gaps in P4 amounted to $6 \%$, and data from a similar rain gauge hereafter referred to as P2 (Fig. 1), located at $4875 \mathrm{~m}$ a.s.l., were used to fill the data gaps. The determination coefficient of daily precipitation amounts between P2 and P4 had only low significance $\left(r^{2}=0.60\right.$, between 2002 and 2008) mainly because snow precipitation occurred more frequently at P2 than at P4, and snow melt in the rain gauge was delayed because the sensors were not artificially heated. Data were quality controlled and validated with monthly total precipitation measured at $4550 \mathrm{~m}$ a.s.l. in the field using a totalizer rain gauge. Although recommended by Wagnon et al. (2009) for snow-specific precipitation gauges, no correction factor was applied to precipitation data recorded by the $\mathrm{P} 4$ rain gauge. Indeed, based on comparisons between accumulation and precipitation measurements, Favier et al. (2008) showed that precipitation measured by pluviometers provides accurate information on precipitation at the summit, and should be representative of the entire catchment. Hence, this precipitation gauge was assumed to be a reference for the whole watershed.

6. Daily air temperature and precipitation values (Table 3) from remote stations were also used. First, data from Izobamba meteorological station (3058 m a.s.l., Fig. 1) from 2000 to 2008 were used as inputs for the PDD model. This station is located $40 \mathrm{~km}$ west of Antizana volcano, a few kilometers south of Quito city, and is the World Meteorological Office station in Ecuador. Comparison of precipitation values from Antizana and Izobamba (1999-2008) showed that daily Izobamba data need to be multiplied by a factor 0.74 to fit observed precipitation on Antizana Glacier $15 \alpha$.

On the interest of positive degree day models for mass balance modeling in the inner tropics

L. Maisincho et al.

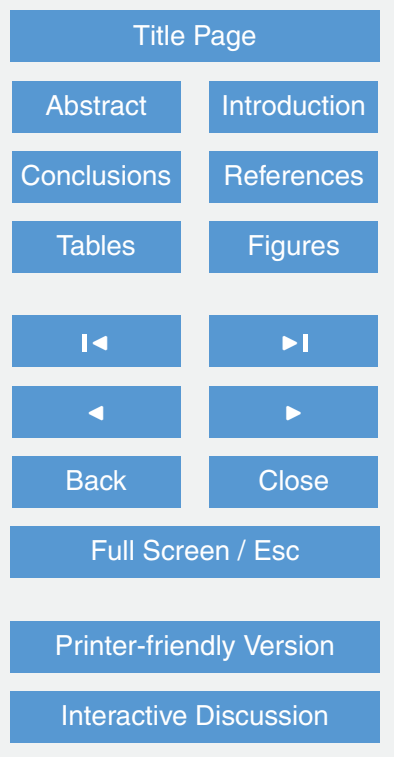


7. Monthly temperature series recorded at Quito meteorological station from 1950 to 1985 were analyzed to assess long-term temperature variations. The station is located in Quito at $2820 \mathrm{~m}$ a.s.I. and provides the longest time series in Ecuador. However, daily values are not available at Quito station, thus preventing the use of our PDD model. As a consequence, our historical PDD modeling used data from Izobamba station from 1964 to 2008, and NCEP1 reanalysis data before 1964.

8. Finally, we used NCEP-NCAR Reanalysis1 (NCEP1) precipitation and air temperature values (Table 3 ) from the closest pixel to Antizana volcano $\left(77^{\circ} \mathrm{W} ; 0.2^{\circ} \mathrm{S}\right)$. NCEP1 are global atmospheric reanalysis data available from 1948 to the present (Kalnay et al., 1996). The NCEP1 model produces 6 hourly data at a T62 spectral resolution $(210 \mathrm{~km})$ and for 28 vertical levels extending from $5 \mathrm{hPa}$ above the surface to a top level of $3 \mathrm{hPa}$ (Kalnay et al., 1996). It uses a sequential $6 \mathrm{~h}$-cycle data assimilation (3-D variational) scheme. NCEP1 data from 2000 to 2008 were used to check whether modeling outputs provide accurate information for regional glacier modeling. The reanalyzed temperature at $570 \mathrm{hPa}$ (4900 m a.s.l.) was linearly interpolated from data at 600 and $500 \mathrm{hPa}$, whereas precipitation was reduced by a factor 0.5 to fit mean field precipitation values between 2000 and 2008 , even though this correction did not remove several discrepancies observed in monthly precipitation amounts using reanalysis data.

$20 \quad$ For long term PDD analysis, NCEP1 data from 1964 to 2008 were compared with Izobamba data to obtain long-term daily temperature and precipitation information. The ratio between cumulative daily precipitation from Izobamba and NCEP1 between 1964 and 2008 was 0.83 but varied with time (Table 4). The ratio was close to unity in the 1960s but decreased considerably after 1975 to reach 0.67 between 2000 and 2008 .

This suggests that the reanalyzed precipitation data should not be directly used for long term mass balance analysis. Here we used NCEP1 data for PDD computations before 1964, when Izobamba data were not available, but used Izobamba data as soon as they became available. For this task, NCEP1 precipitation from 1950 to 1963

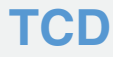

8, 2637-2684, 2014

On the interest of positive degree day models for mass balance modeling in

the inner tropics

L. Maisincho et al.

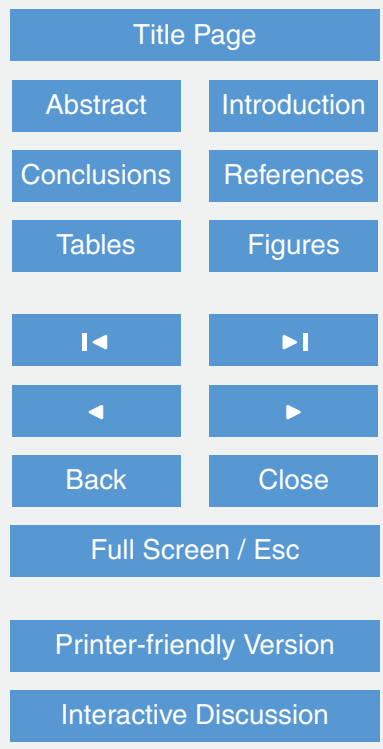


was corrected, multiplied by the ratio observed in the 1960 s (i.e. 1.10) to retrieve the mean precipitation observed at Izobamba. Then, in the same way as for Izobamba precipitation, these data were additionally corrected by a factor of 0.74 to fit the mean field precipitation at Antizana, as explained above.

\section{3.3.2 Glaciological data}

In this study we used (Table 3):

1. daily melting amounts for 43 days in 2002-2003 obtained using "melting boxes" described in Favier et al. (2004a). A melting box, similar to those described by Wagnon et al. (1999), is a cylindrical box with a $50 \mathrm{~cm}$ radius with a gridded bottom, which is filled with snow or ice. This box is placed inside a slightly bigger box in which snow or ice melt collects. The melting box is inserted in the snow or ice to reproduce the surface condition of the glacier as faithfully as possible. The weight of these boxes is measured at regular intervals (with a precision of $\pm 1 \mathrm{~g}$ ). In the study by Favier et al. (2004a), special care was taken to discard all measurements disturbed by liquid precipitation in the boxes.

2. The annual Antizana $15 \alpha$ vertical mass balance profiles (VBP) were computed from field measurements and the ELA from 2000 to 2008 (Basantes Serranoet al., 2014). All details regarding the glaciological measurements and methods are described in Francou et al. (2004).

3. The Antizana $15 \alpha$ glacier-wide annual mass balance $(\mathrm{Ba})$ of from 2000 to 2008 computed from field measurements. Here we present data from Basantes Serrano et al. (2014), in which the glacier-wide annual mass balance of the Antizana Glacier $15 \alpha$ computed using the glaciological method was recalculated using a new, more accurate delimitation of the glacier; and adjusted with the geodetic method which uses digital elevation models (DEM) made from aerial photographs taken in 1997 and 2009 to compute the volume changes of the entire glacier

On the interest of positive degree day models for mass balance modeling in the inner tropics

L. Maisincho et al.

\section{Title Page}

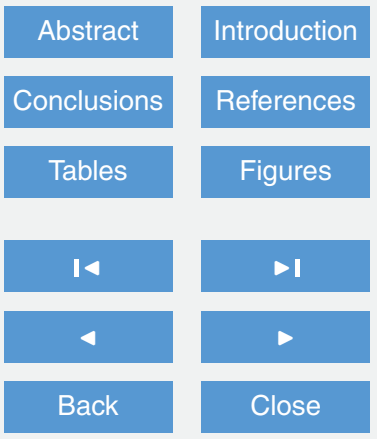

Full Screen / Esc

Printer-friendly Version

Interactive Discussion 
surface. Basantes Serrano et al. (2014) showed that on Antizana Glacier $15 \alpha$ the cumulative mass balance computed using the glaciological method differed significantly from the one computed using the geodetic method, so that the adjustment by the geodetic method was indispensable to accurately quantify the annual mass balance. The discrepancy between the two methods has several causes, but the main cause is that inaccurate interpolation of the mass balance values is done over the glacier surface area where no measurements are conducted. This represents more than $60 \%$ of the glacier surface area. This is the case between the accumulation (at about 5300 ma.s.I.) obtained from the lowest elevation pit or snow core and from the highest ablation stake (at about 5000-5050 m a.s.I.). As a consequence, the shape of the VBP there is conjectural. This inaccurate estimation of accumulation results in significant underestimation of the total mass balance (which can reach $60 \%$ for some years). The reader should refer to Basantes Serrano et al. (2014) for more details. Hereafter, the adjusted specific mass

4. The modeled VBP values were spatially interpolated to assess the modeled glacier-wide annual mass balance. Interpolation required incorporating the point mass balance over the entire surface area of the glacier. For this task, we assumed that the point mass balances were representative of the mean glacier mass balance over specific surface areas of the glacier. We assumed the same area as the one used for field glacier-wide mass balance computations. Hence, the annually updated hypsometry and glacier surface area of the Antizana Glacier $15 \alpha$ computed by Basantes Serrano et al. (2014) using the 1997 and 2009 digital elevation models established using aerial photogrammetry and the annual topographical measurements of the glacier tongue outline were used to compute the glacier-wide annual mass balance with the PDD model.

5. Finally, intermittent observations and terrestrial photographs (Table 3) of the glacier surface which were made to estimate the elevation of the snowline on

On the interest of positive degree day models for mass balance modeling in the inner tropics

L. Maisincho et al.

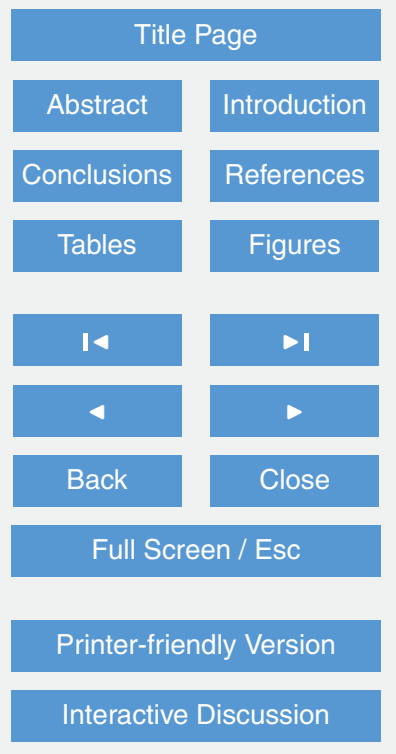


the glacier during field trips between 2004 and 2008 were used. The daily snowline elevation was also estimated from photographs obtained with a low resolution automatic camera (Fujifilm FinePix 1400) installed on the frontal moraine at $4785 \mathrm{~m}$ a.s.l. These photographs were taken from the location point called "Photo" in Fig. 1, and were georeferenced (Corripio, 2004). The georeference and contrast between ice and snow on the pixels of each photographs enabled us to retrieve the daily snowline for a period of five years (2004 to 2008). A total of 712 good quality daily photographs allowed us to almost continuously monitor the snowline elevation over time. The elevation was obtained with an accuracy of $\pm 10 \mathrm{~m}$.

\section{Results and discussion}

\subsection{Estimating degree-day factors for snow and ice}

The mean daily temperature and the cumulative hourly positive temperature values at daily time step were first compared with melting amounts from field measurements obtained with melting boxes placed close to the AWS in 2002-2003. The surface state of the contents of the boxes was observed and recorded during field campaigns to allow separation into different classes: snow or ice. We also observed that clean and dirty ice should be separated because much more melting took place in the case of dirty ice, despite the minor differences in incoming fluxes and in mean measured temperature. As a consequence, we created three classes: snow, clean ice and dirty ice (Fig. 2). A comparison between albedo values measured at the AWS and the initial classification between the different surface states suggests that dirty and clean ice can be separated assuming an albedo threshold of 0.35 (Fig. 2). It was more difficult to detect a threshold between snow and clean ice, as clean ice albedo may occasionally exceed that of snow. This is mainly because of the patchy distribution of snow on the surface of the glacier during the period when the "melting box" experiment was conducted. Indeed, the $\mathrm{AWS}_{\mathrm{G} 1}$ and the melting box were separated by a few meters, and
On the interest of positive degree day models for mass balance modeling in the inner tropics

L. Maisincho et al.

Title Page

Abstract Introduction

Conclusions References

Tables Figures

14

$\Delta 1$

4

Back

Close 
snow may remain below the pyranometer, whereas the surface of the melting box was free of snow. Thus, albedo measurements were not always representative of the surface state of the melting box. A typical albedo threshold between snow and clean ice surfaces of 0.6 was consequently assumed. However, despite this classification, mean 5 daily temperature was poorly correlated with the measured melting rates (Fig. 3a).

Data suggest that melting often starts even when the mean daily air temperature is negative. Indeed, over the 43 days of direct field observations with significant melting amount, we observed that the mean daily air temperature was negative for nine days. For example, a daily melting of $3.8 \mathrm{~mm} . \mathrm{w} . \mathrm{e}^{\mathrm{d}} \mathrm{d}^{-1}$ on 31 July 2002 was observed when 10 the mean daily air temperature was $-1.3^{\circ} \mathrm{C}$. This situation has already been observed in Greenland (Van den Broeke et al., 2010), where a $-5^{\circ} \mathrm{C}$ threshold was necessary to remove modeling biases caused by the occurrence of short periods of melting when significant nocturnal refreezing occurred. Indeed, these periods were characterized by negative mean daily air temperatures due in particular to unbalanced longwave budgets at night, but also by major incoming shortwave radiation leading to diurnal melting.

The correlations were more significant when we assumed the cumulative hourly positive temperature values computed at a daily time step (Fig. 3b). Surprisingly, the latter correlations were similar to those obtained between measured melting amounts and estimated values using a surface energy balance approach for clean ice (Fig. 3c). The PDD approach performed even better for snow surfaces. This may be due to the occasional differences in the surface state below the pyranometer and on the surface of the melting boxes. Indeed, the air temperature was not impacted by small scale variations in albedo, which on the other hand, had a major impact on surface energy balance computations. This was particularly true in the case of patchy snow surfaces. Moreover, measurement uncertainties for melting and surface energy balance may partly explain this paradox. We assumed that the agreement between measured melting amount and cumulative hourly positive temperature values was sufficient to calibrate the degreeday factor values for snow, clean ice and dirty ice. This led to three degree-day factors for snow $\left(F_{\text {snow }}=4.9 \mathrm{~mm}\right.$.w.e. $\left.\mathrm{K}^{-1} \mathrm{~d}^{-1}\right)$, clean ice $\left(F_{\text {clean_ice }}=6.5 \mathrm{~mm} . \mathrm{w} . \mathrm{e} \cdot \mathrm{K}^{-1} \mathrm{~d}^{-1}\right)$ and

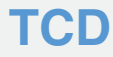

$8,2637-2684,2014$

On the interest of positive degree day models for mass balance modeling in the inner tropics

L. Maisincho et al.

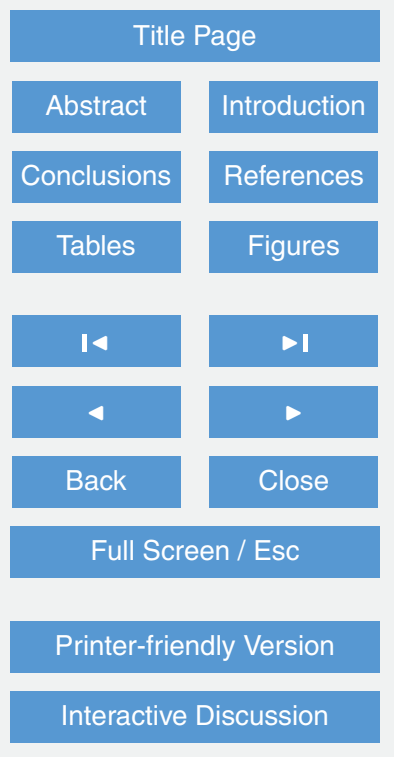


dirty ice $\left(F_{\text {dirty_ice }}=12.7 \mathrm{~mm} . \mathrm{w} . \mathrm{e} \cdot \mathrm{K}^{-1} \mathrm{~d}^{-1}\right)$. Managing the distinction between clean and dirty ice is not easy for PDD modeling. For this reason, we included data from dirty and clean ice melting boxes in the same category. Even if this yields lower correlations between cumulative degree-day and melting, a degree-day factor for ice was 5 computed, $F_{\text {ice }}=9.8 \mathrm{~mm}$.w.e. $\mathrm{K}^{-1} \mathrm{~d}^{-1}$. The $F$ values were similar to those obtained for other glaciers (Radic and Hock, 2011), even though assuming dirty ice conditions led to a slightly higher coefficient for Antizana 15 Glacier than for other glaciers. These values initially reflect a correlation between melting and temperature at a 30 min time scale, but we assumed the values are also valid at a daily time scale.

The cumulative hourly positive temperature values were compared to the mean local energy fluxes to check whether a correlation between melting and temperature could be explained by the local processes. We first analyzed data on days with direct melt measurements (Fig. 4) because on these days, sublimation was calibrated with lysimeters, and we consequently had more confidence in our computed values of turbulent 15 heat fluxes. Except during Period 1 when high winds and low moisture induced high turbulent heat fluxes, the cumulative hourly positive temperature values were significantly correlated with incident shortwave radiation and with the net shortwave radiation (S) (Fig. 4a and b). Indeed, due to significant local air mixing, air temperature was closely correlated with surface temperature (when $<0^{\circ} \mathrm{C}$ ) and to the duration of diur20 nal melting, which mainly depended on the net energy stored at the surface. Thus, if we refer to the period from 14 March 2002 to 31 March 2003, the relationship between air temperature and melting makes sense, because the net shortwave radiation was by far the most important variable involved in melting processes $(r=0.78, n=376)$ and in surface temperature. The correlations with other fluxes were not significant (Fig. 4c-f). 25 Turbulent heat fluxes $(\mathrm{LE}+H)$ were generally close to zero because LE and $H$ were opposite and compensated for each other, except during Period 1 (Fig. 4f). This had a direct impact on the relationship between temperature and melting in Period 1, because turbulent heat fluxes were not negligible during this period and exerted important control over ablation. This meant that air temperature had to be used with caution when

On the interest of positive degree day models for mass balance modeling in the inner tropics

L. Maisincho et al.

Title Page 
estimating ablation in Period 1. Nevertheless, the discrepancy was limited because the high sublimation amounts were also associated with lower temperatures in Period 1 than during the rest of the year. Thus, computing melting with cumulative hourly positive temperature values led to low melting values during Period 1, in agreement with 5 the decrease in melting caused by the highly negative latent heat flux during this period (Favier et al., 2004a).

\subsection{Validation of degree-day factors over the 2002-2003 period}

To test the accuracy of the degree-day factors derived in Sect. 4.1, we computed daily melt over one annual cycle (2002-2003) using the degree-day model, and compared them with melting results of the SEB computation (Favier et al., 2004a). The melting resulting from SEB computation is hereafter referred to as SEB melting.

We first analyzed whether the mean daily temperature values could be used to run the PDD model instead of the cumulative hourly positive temperature values. At an annual timescale, without separating snow and ice surface states, the correlations bescale) and daily SEB melting were similar and quite low ( $r=0.58$ in both cases, for 376 days). Because the interest of PDD modeling is being able to estimate the impact of past and future climate on glaciers, and since historical hourly temperature data are not available, we analyzed whether mean daily temperature would allow the daily melting to be modeled.

We separated days according to their surface state (snow, clean ice and dirty ice). We then multiplied the mean daily temperature by the corresponding $F$ value from Sect. 4.1. The resulting melting values are hereafter referred to as $T /$ melting. We first assumed that snow was present at the $\mathrm{AWS}_{\mathrm{G} 1}$ station when the albedo was higher than

0.6 and that ice was dirty when the albedo was lower than 0.35 , while clean ice conditions were assumed when the albedo was within these two boundaries. This separation only led to a correlation between the $T /$ melting and the SEB melting of $r=0.60$ (for 376 days). However, optimization of the albedo thresholds between clean ice and dirty

On the interest of positive degree day models for mass balance modeling in the inner tropics

L. Maisincho et al.

Title Page

Abstract Introduction

Conclusions References

Tables Figures

14 $>1$

4

Back

Close

Full Screen / Esc

Printer-friendly Version

Interactive Discussion 
ice (albedo $=0.45$, instead of 0.35 ) led to a higher correlation between the $T / \mathrm{melting}$ and the SEB melting ( $r=0.76, n=376$ days, Fig. 5a). Nevertheless, as mentioned in Sect. 4.1., in order to obtain the same melting amounts during the 2002-2003 period we had to assume that melting began when the daily temperature was negative. 5 Indeed, observations showed that melting was frequently significant when the mean daily temperature was still negative (Fig. 6). And in fact, this had a major impact on $T /$ melting values, because melting amounts were underestimated if we considered that melting began only when mean daily air temperature was $0^{\circ} \mathrm{C}$. Calibration of this threshold was performed to retrieve the magnitude of SEB melting amounts with the 10 PDD model, which yielded a threshold value of $-1.9^{\circ} \mathrm{C}$. A frequency analysis showed that $3 \%$ of the melting events in 2002-2003 happened at a mean daily temperature below $-1.9^{\circ} \mathrm{C}$ (Fig. 6), meaning this optimized value was justified. Hereafter, a threshold of $-1.9^{\circ} \mathrm{C}$ was assumed for PDD modeling. With this assumption, we observed that the mean daily temperature yielded high correlations with SEB melting, and that the 15 annual melting cycle was accurately reproduced (Fig. 5a). The marked difference in melting amounts between Period 1 and Period 2 was reproduced, demonstrating that taking sublimation, or more generally turbulent heat fluxes, into account is not a major limitation to the use of PDD models in Ecuador.

To understand this significant correlation, we compared the $T$ /melting with the differ20 ent energy fluxes recorded at the $\mathrm{AWS}_{\mathrm{G} 1}$. A significant correlation was found between the $T /$ melting and the net shortwave radiation $S(r=0.71, n=376$ days). A moving correlation between $S$ and the $T$ /melting over 30 days showed variations over the annual cycle. This correlation generally reached 0.8 when temperature presented significant variations over a period of one month. However, the correlation decreased when there were no variations in temperature over a long period. This was the case in the study period used by Sicart et al. (2008), partly explaining the low correlation reported by these authors. However, we observed that $T /$ melting values during the latter period presented significantly higher correlations with SEB melting than the mean daily

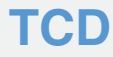

8, 2637-2684, 2014

On the interest of positive degree day models for mass balance modeling in the inner tropics

L. Maisincho et al.

\section{Title Page}

Abstract

Conclusions

Tables

14

4

Back

Full Screen / Esc

Printer-friendly Version

Interactive Discussion 
temperature values used in the study by Sicart et al. (2008), because albedo is a key driver of melting (Favier et al., 2004a).

Ultimately, and importantly, we decided that melting conditions can be distinguished according to two surface classes only, i.e. ice and snow. We thus assumed that melting

5 was computed with $F_{\text {ice }}$ when albedo was lower than 0.45 and with a higher $F_{\text {snow }}$ than this value. This produced similar correlations to our previous analysis $(r=0.75$, $n=376$ ) and the mean annual melting value was still respected (only $12 \%$ lower than the melting computed with the SEB). As a consequence, correctly distinguishing ice and snow and obtaining the corresponding degree-day factors allowed us to retrieve 10 variations in melting even when temperature only presented low magnitude variations.

\subsection{PDD modeling of the period 2000-2008}

\subsubsection{Modeling of the distributed surface mass balance}

Degree-day factors for ice $\left(F_{\text {ice }}\right)$ and for snow $\left(F_{\text {snow }}\right)$, and the threshold temperature from Sects. 4.1 and 4.2 were assumed to enable melting modeling using the mean 15 daily temperature and precipitation recorded from 2000 to 2008 at 4900 m a.s.I. in the vicinity of Antizana Glacier $15 \alpha$. The PDD model was applied at every elevation range, assuming that sublimation is negligible, and compared to the surface mass balance (SMB) measurements made on the glacier. Indeed, sublimation represents about $4 \%$ of total ablation at 4900 ma.s.l. (Favier et al., 2004). This rate may increase with elevation as melting amounts decrease, but its variations with elevation are not correctly known.

Overall, the modeled VBP agreed with the observed VBP (Fig. 7). The point mass balance was correctly modeled at the summit and in the ablation zone. Nevertheless, we noted several discrepancies in our modeling results. Differences were observed for the VBP in 2002, whose trend was poorly reproduced above $4850 \mathrm{~m}$ a.s.l., and in 2003, where ablation was particularly high at low elevations. Conversely in 2006, simulated ablation was higher than measured ablation at low elevations. Accumulation

On the interest of positive degree day models for mass balance modeling in the inner tropics

L. Maisincho et al.

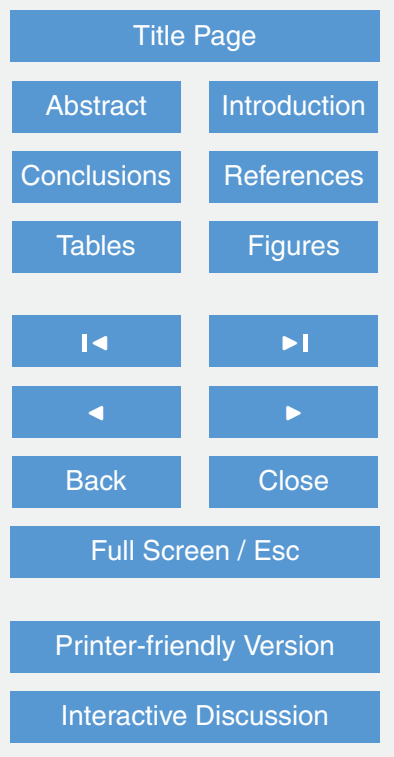


was generally correctly assessed, even though the model sometimes suggested more accumulation than observed (in 2001 and 2002 for instance) which might result from both measurement uncertainty and the inability of the model to exactly reproduce processes at high elevations. Moreover, the lowest elevation accumulation data in 2008 5 was doubtful, leading to highly inaccurate surface mass balance interpolation and to incorrect assessment of the ELA.

However, the largest discrepancy was the incorrect reproduction of point mass between 5000 and $5300 \mathrm{~m}$ a.s.I. This discrepancy was very likely due to the interpolation of SMB values between the ablation measured at the highest elevation and accumula- tion measured at the lowest elevation (Basantes Serrano et al., 2014). Modeling confirmed this point (Fig. 7) and the SMB profiles in this area are unlikely to vary linearly. We observed that the discrepancies between modeled and measured point mass balance were lower when the measurements were made close to the ELA (i.e. in 2001). Conversely, the discrepancy was high when the linear interpolation between the lowest elevation snow pit and the highest elevation ablation stake strongly deviated from the SMB profiles due to lack of field measurements close to the ELA.

On the other hand, with the assumed $F_{\text {ice }}$ value, the modeled ablation in the ablation zone was generally slightly overestimated, except in 2002 and 2003. Albedo measurements made on the ablation zones of glaciers 15 and 12 between 1999 and 2008 (Glacier 12 is also called Los Crespos Glacier, e.g., Cauvy et al., 2013) showed that albedo was particularly low during the 2002-2003 cycle, suggesting that the ice was frequently dirty (Fig. 8). In particular, albedo values in 2002 and 2003 were frequently below 0.3 (missing data between 17 December 2001 and 14 March 2002 are not accounted for in Fig. 8, which would have increased the number of occurrences in 2002).

25 This situation occurred less frequently during the other years of study, suggesting that the ice was more often clean. The PDD model was thus applied again, but this time using the clean ice degree-day factor $\left(F_{\text {clean_ice }}=6.5 \mathrm{~mm}\right.$.w.e. $\left.\mathrm{K}^{-1} \mathrm{~d}^{-1}\right)$ for ice (Fig. 7), which resulted in a clear improvement in years with high albedo. This difference confirms that the degree-day factors may differ for different periods of time (e.g., Huss and

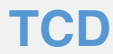

8, 2637-2684, 2014

On the interest of positive degree day models for mass balance modeling in the inner tropics

L. Maisincho et al.

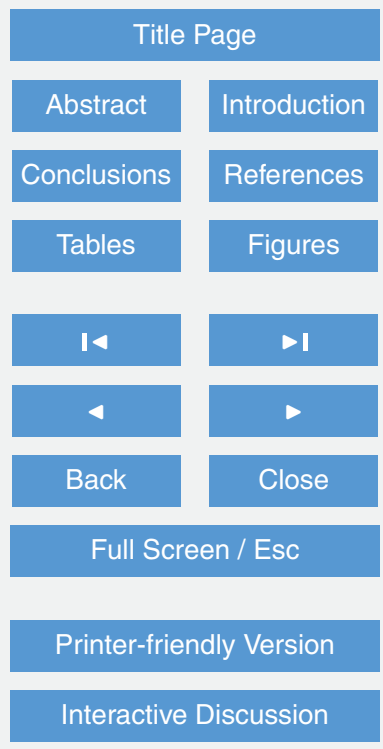


Bauder, 2009) reflecting variations in albedo (since degree-day factors for ice differ depending on the surface state). Again, melt variability is mainly determined by variations in incoming short wave radiation and melt-albedo feedback, whereas other SEB terms most closely linked with temperature $(L \downarrow$, LE and $H)$ are not significantly cor5 related with ablation. Hence, using a model that includes incident shortwave radiation may partly reduce the discrepancy observed in the case of low albedo (e.g. Pellicciotti et al., 2005). However, obtaining accurate forecasts or reconstructions for radiation at a regional scale requires a more complex approach than for temperature, and the application of such a model would require additional downscaling steps, which would reduce the interest of the PDD approach compared to SEB computations.

Next, our computed glacier-wide annual mass balances were integrated over the whole glacier area and compared to the specific mass balance from Antizana Glacier $15 \alpha$ (Basantes Serrano et al., 2014). Assuming $F_{\text {clean_ice, }}$, we observed that the modeled annual mass balance values were close to the measured glacier-wide annual 15 mass balance $\left(r^{2}=0.71, n=9\right.$ years). The model produced very similar mean losses to the geodetic mass balance over the entire period (difference of $0.07 \mathrm{mw}$.e. $\mathrm{a}^{-1}$ over 9 years). This high correlation suggests that temperature and precipitation are the main climatic drivers of glacier mass balance at the regional scale. Moreover, we observed a significant increase in correlations if the degree-day factor $F_{\text {dirty_ice }}=$ $209.8 \mathrm{~mm}$. w.e. $\mathrm{K}^{-1} \mathrm{~d}^{-1}$ (see previous paragraph) was used in 2002 and $2003\left(r^{2}=0.89\right.$, $n=9$ years). However, the slope of the regression line between the modeled and the measured glacier-wide annual mass balances was larger than 1 (Fig. 9). Removing the modeling result for the year 2003 led to a slope value closer to unity (slope $=1.12$, assuming $F_{\text {clean_ice }}$ for every year except 2002). This suggests that the steeper slope of the regression line mainly resulted from the model's overestimation of the very negative mass balance in years when the albedo was low. However, this slope value might also be partly the result of methodological inconsistencies when the glacierwide mass balance is computed with the glaciological method when the glacier-wide annual mass balance value is very negative (even after geodetic correction). Indeed,

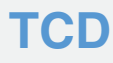

8, 2637-2684, 2014

On the interest of positive degree day models for mass balance modeling in the inner tropics

L. Maisincho et al.

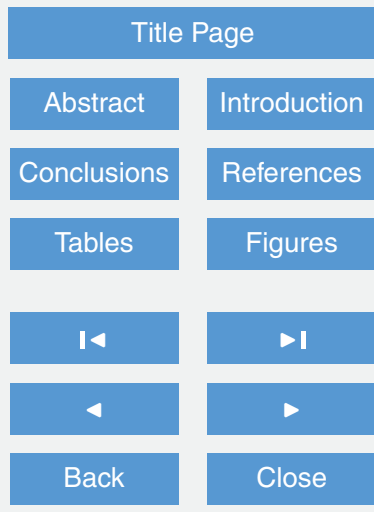

Full Screen / Esc

Printer-friendly Version

Interactive Discussion 
the linear interpolation between 5050 and 5300 ma.s.l. resulted in underestimation of the glacier-wide annual mass balance when this area was characterized by high ablation (Fig. 7). Figure 7 suggests that the higher the ELA, the larger the uncertainty in the glacier-wide annual mass balance calculated with the glaciological method. The 5 geodetic adjustment is not designed to remove such annual errors, because instead, it distributes corrections of the cumulative errors over each annual value. Even if the uncertainties in the glacier-wide annual mass balance related to the interpolation concern lower values than the geodetic adjustment itself, this suggests that the measured glacier-wide annual mass balance is slightly lower than the one shown in Fig. 9, partly

\subsubsection{Modeling the snowline and ELA variations}

For further validation of the model, we compared the modeled vs. measured annual ELA, and modeled vs. measured snowline at a shorter time step. The modeled and measured snowline elevations were averaged over 15 days to reduce the impact of the precipitation uncertainty on model results. Indeed, because the tipping bucket rain gauges are not artificially heated, the snow can accumulate inside the funnel and naturally melt several hours or even a day after the precipitation occurred. This led to several shifts in the modeled daily snowline time series.

The modeled snowline was in good agreement with the measured snowline $\left(r^{2}=\right.$ $0.75, n=91$, based on 15 day periods, Fig. 10), demonstrating that the model accurately represented the altitudinal distribution of accumulation and ablation at a short time scale. This good agreement is partly due to the direct link between solid precipitation and the $0^{\circ} \mathrm{C}$ level (e.g., Favier et al., 2004a, b; Francou et al., 2004). The modeled annual ELA was also in good agreement with the measured ELA $\left(r^{2}=0.77\right.$, $25 n=9$ years), a direct consequence of the good agreement between the modeled and the observed snowline.

On the interest of positive degree day models for mass balance modeling in

the inner tropics

L. Maisincho et al.

Title Page 


\subsection{Using the PDD model with data from remote stations or reanalysis data}

The glacier-wide annual mass balances were computed using $F_{\text {snow }}=$ $4.9 \mathrm{~mm}$. w.e. $\mathrm{K}^{-1} \mathrm{~d}^{-1}$ ) and $F_{\text {clean_ice }}=6.5 \mathrm{~mm} . \mathrm{w} \cdot \mathrm{e} \cdot \mathrm{K}^{-1} \mathrm{~d}^{-1}$, for the 2000-2008 period using data from a remote meteorological station located at Izobamba. Because

5 data were measured at distinct elevations and under slightly different climatic settings, a correction was applied on Izobamba temperature and precipitation data to obtain similar mean values to those at $4900 \mathrm{~m}$ a.s.l. during the 2000-2008 period.

First, the model was applied using temperature data from Izobamba, which were corrected with a lapse rate of $-6.0^{\circ} \mathrm{C} \mathrm{km} \mathrm{m}^{-1}$ to retrieve similar mean annual values 10 as those observed on Antizana over the period 2000-2008. The experiment revealed a significant correlation between the observed and the computed glacier-wide annual mass balances $\left(r^{2}=0.72, n=9\right.$ years, Fig. $\left.9 b\right)$, suggesting that temperature variations at Izobamba meteorological station were representative of the regional climate responsible for the glacier retreat observed over the last decade. In the second step, 15 we applied the model to both temperature and precipitation at Izobamba. To reduce the bias in precipitation amounts caused by regional features and differences in elevation, Izobamba data were multiplied by a factor of 0.74 to fit the precipitation observed on Antizana Glacier $15 \alpha$. This modeling resulted in a slightly lower correlation with measured data $\left(r^{2}=0.63, n=9\right.$ years, Fig. $\left.9 b\right)$, suggesting that the occurrence and amounts of precipitation are very important for the computation of the glacier mass balance at an annual scale.

Next, we applied the PDD model on NCEP1 data assuming that precipitation should be multiplied by a factor 0.5 (as mentioned in Sect. 3.3.1), whereas the reanalyzed temperature at $570 \mathrm{hPa}(4900 \mathrm{~m}$ a.s.l.) was linearly interpolated from data at 600 and $500 \mathrm{hPa}$. The results of this experiment were in good agreement with measured values $\left(r^{2}=0.73, n=9\right.$ years, Fig. $\left.9 \mathrm{~b}\right)$. However, the snowline was not correctly modeled (data not shown) demonstrating that accurate precipitation amounts are crucial for the correct modeling of this variable.

On the interest of positive degree day models for mass balance modeling in

the inner tropics

L. Maisincho et al.

Title Page 
Finally, given the close relationship between temperature and melting, we wanted to explain the occurrence of the almost equilibrated mass balances in Ecuador between 1956 and 1976 as suggested by studies on Antizana glacier (e.g., Francou et al., 2000; Basantes Serrano et al., 2014) and on the neighboring Cotopaxi Volcano (Jordan et al., 5 2005). To this end, we analyzed the long term temperatures measured in the field and temperatures from NCEP1 reanalysis and those recorded at Quito meteorological station. Both temperature time-series were in agreement in suggesting that a slight cooling occurred during the 1960s and at the beginning of the 1970s (Fig. 11), whereas atmospheric warming has been recorded since the end of the 1970s (Vuille and Bradley, 10 2000; Vuille et al., 2008).

Next, PDD modeling was performed to retrieve variations in the ELA. Figure 11a shows that the reanalyzed temperatures were in good agreement with historical temperatures recorded at Quito. However, we observed that precipitation data from NCEP1 increased excessively compared with observed precipitation after 1976 and we thus 15 preferred to use measured precipitation at Izobamba instead. We consequently produced a PDD model based on the daily reanalyzed temperature but using Izobamba precipitation for the period between 1964 and 2008. However, we were nevertheless obliged to use reanalyzed precipitation time series before 1964 due to the lack of daily precipitation measurements. To this end, NCEP1 daily precipitation was corrected using the difference in ratio with Izobamba (see Sect. 3.3.1.5). The modeled ELA for the 2000-2008 period was in good agreement with the measured ELA $\left(r^{2}=0.86, n=9\right.$, data not shown) suggesting that this PDD model was sufficiently accurate to analyze past variations in ELA over time.

Modeling showed good agreement between the modeled ELA (Fig. 11) and the above mentioned glacier advance in the 1960s and the 1970s (Rabatel et al., 2013) confirming that the occurrence of a cool period explained the pause in glacier retreat. Because no DEM was available before 1995, it was not possible to compute accurate glacier-wide mass balance before this date, as a consequence, we only modeled ELA changes.

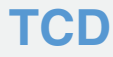

8, 2637-2684, 2014

On the interest of positive degree day models for mass balance modeling in the inner tropics

L. Maisincho et al.

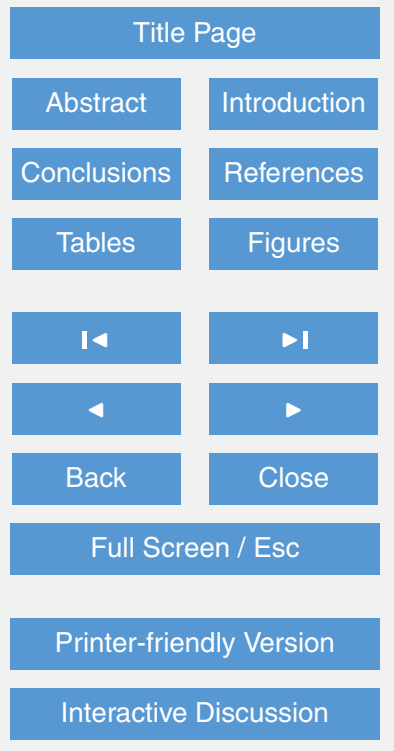




\section{PDD sensitivity}

A sensitivity test of the computed specific mass balance was performed on the main model parameters: (Table 5) the temperature threshold, the degree-day factors for ice and snow, and the temperature lapse rate with elevation. This test showed that the 5 model was particularly sensitive to the temperature threshold because this parameter directly increased both snow and ice melting. Nevertheless, the value was quite robust as it was obtained from different consistent approaches. The degree-day factor for ice was also crucial because it controlled melting in the lower part of the glacier, i.e. where melting was very high. The correlation coefficient between the melting boxes and tem10 perature were slightly more significant for ice, suggesting that this factor was correctly assessed. But we also demonstrated that this parameter can change depending on the surface state. It may thus be important to better constrain this parameter in the future. Here, we tried to better constrain this parameter with a regression analysis between ablation obtained from stakes positioned in the field and positive degree day sums at 15 a monthly scale. Unfortunately, due to systematic alternation of snow and rainfall events at the surface of the lower part of the glacier, it was not possible to separate ice and snow surfaces, or to extract accumulation from point mass balance measurements at the stake locations. Concerning the degree-day factor for snow, this parameter had less impact on the final model because it mainly acted on melting in the highest part of the glacier, where the temperature was usually negative. Nevertheless, its value would be crucial in cold snowy years (during La Niña events), i.e., when conditions are favorable for glacier mass gains. Finally, the lapse rate was accurately obtained from measurements in the field, and had no marked impact on the final mass balance values.

\section{Conclusion}

25 The good agreement between temperature and glacier melting and mass balance found on the Antizana glacier is not casual because it is based on similar relationships
On the interest of positive degree day models for mass balance modeling in

the inner tropics

L. Maisincho et al.

\section{Title Page}

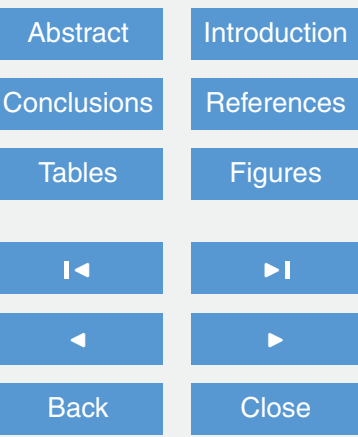

Full Screen / Esc

Printer-friendly Version

Interactive Discussion 
than those observed under other latitudes. Despite the low annual temperature variations (less than $3.5^{\circ} \mathrm{C}$, based on daily means), our experiments with melt boxes revealed a significant correlation between cumulative positive degree days and melting if a distinction was made between ice and snow. The comparison between temperature 5 and the energy fluxes demonstrated that both air temperature and surface melting were closely linked to the net shortwave radiation budget through the impact of the albedo mainly controlled by the phase of precipitation. The comparison also suggests that PDD modeling should not be applied in the case of high sublimation. Nevertheless, in our case, the consequences were limited for the mean monthly melting because sublimao tion events generally occurred when temperatures and melting on the glacier were low. This study showed that variations in the annual mass balance were particularly well reproduced when the temperature was accurately assessed and when the model enabled correct estimation of the surface state (i.e. indirectly of the surface albedo). Modeling results also suggest that the degree-day factors should be adapted according to the mean annual surface albedo, because clean and dirty ice surfaces do not respond in the same way to incoming short wave radiation. This suggests that degree-day factors should be recalibrated for reconstructions of past or future climate. In that sense, we demonstrated that a clean ice degree-day factor was more appropriate for PDD modeling, except for years with a very dirty surface. Hence, due to the marked differences between melting amount depending on ENSO climatic variability (e.g., Francou et al., 2004), the latter observation suggests that the "mean ice" degree-day factor should be used during El Niño events, whereas the clean ice melt factor should be used during La Niña events. As a consequence, reconstruction of ENSO variability using other proxies, or forecasts of ENSO phases, will be very useful for modeling past or future mass balances. Several results also suggest that melting began when the daily mean air temperature $2 \mathrm{~m}$ above the surface of the glacier was still negative. If a possible negative threshold for temperature is not accounted for, a new calibration of the degree-day factors would be needed, which would lead to higher degree-day factor values. Finally, we demonstrated the interest of using the PDD model to estimate the snowline and

\section{TCD}

$8,2637-2684,2014$

On the interest of positive degree day models for mass balance modeling in

the inner tropics

L. Maisincho et al.

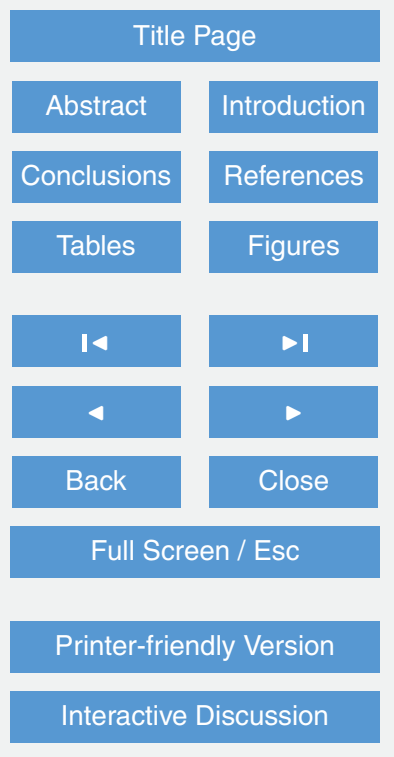


ELA. The good relationships between measured and modeled snowline and ELA were partly caused by the role of the $0^{\circ} \mathrm{C}$ level in the occurrence of solid precipitation, but also relied on accurate computation of melting with the model.

Judging the feasibility of using the PDD model in the inner tropics was crucial to 5 enable the widespread application of such a simple method to retrieve melting from remote areas where only few data are available, or for the reconstruction of past climatic conditions for which climate modeling is the only possible source of data. Given our limited knowledge of past climate forcing, temperature is generally assumed to be the only variable that climate models correctly reproduce. Our results show that 10 temperature data obtained about $50 \mathrm{~km}$ from the study site led to correct modeling results, thereby demonstrating that air temperature represents the main characteristics of regional climate variability. This point is crucial for past and future climate modeling, because downscaling steps are not indispensable if a correction for current mean temperature and precipitation is undertaken.

15 The Antizana glaciers have retreated more than $30 \%$ since 1950 (Francou et al., 2000; Rabatel et al., 2013), and temperatures in the tropical Andes have increased by up to $0.68^{\circ} \mathrm{C}$ since 1939 (Vuille et al., 2008). Because several studies suggest that atmospheric warming will accelerate in the future and may reach up to $5^{\circ} \mathrm{C}$ at the end of the 21st century (e.g., Vuille et al., 2008; Urrutia and Vuille, 2009), the ELA may rise $600 \mathrm{~m}$ and reach almost the elevation of Antizana summit. In these conditions, Antizana glaciers would disappear, which will have major consequences for local water supplies. Knowing the exact range of future temperature change is thus crucial to assess its impact on local water resources.

Acknowledgements. This work was supported by IRD (French Research Institute for Development), in collaboration with the INAMHI (Instituto NAcional de Meteorología e HIdrología), the EPMAPS (Empresa Pública Metropolitana de Agua Potable y Saneamiento de Quito), and the EPN (Escuela Politécnica Nacional de Quito), the IRD program LMI- GREATICE, the French Service d'Observation GLACIOCLIM, JEAI-IMAGE and SENESCYT-EPN PIC-08-506. M. L. Maisincho is grateful to AIRD for providing financial support for his PhD. We thank INAMHI 30 and EPN for providing the meteorological data from Izobamba and Quito station respectively.

2664

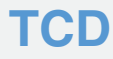

$8,2637-2684,2014$

On the interest of positive degree day models for mass balance modeling in the inner tropics

L. Maisincho et al.

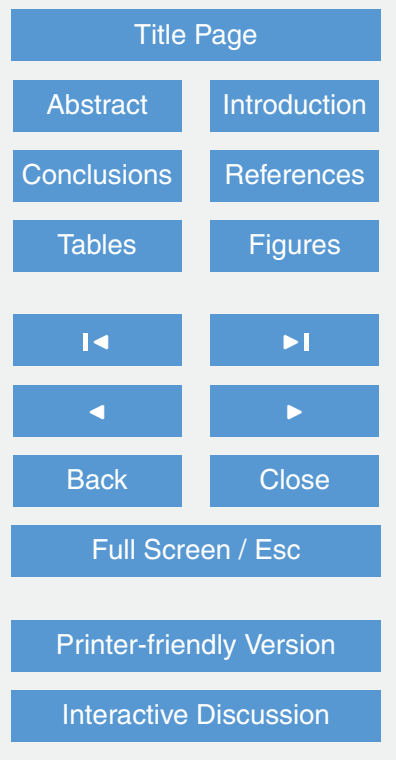


Reanalyzed data were provided by the NOAA/OAR/ESRL PSD, Boulder, Colorado, USA, from their Web site at http://www.esrl.noaa.gov/psd/. Special thanks M. Calispa (EPN), J. Carvajal and R. Felix (INAMHI) for support in the office and in the field, sometimes in harsh conditions.

\section{References}

5 Azam, M. F., Wagnon, P., Vincent, C., Ramanathan, A., Linda, A., and Singh, V. B.: Reconstruction of the annual mass balance of Chhota Shigri glacier, western Himalaya, India, since 1969, Ann. Glaciol., 55, 69-80, doi:10.3189/2014AoG66A104, 2014.

Basantes Serrano, R., Rabatel, A., Caceres, B., Maisincho, L., and Francou, B.: Mass balance evolution on two benchmark glaciers in the Equator $\left(0^{\circ} 28^{\prime} \mathrm{S}\right)$ since the mid-20th century, using geodetic and glaciological methods, The Cryosphere, in preparation, 2014.

Blard, P. H., Lavé, J., Pik, R., Wagnon, P., and Bourlès, D.: Persistence of full glacial conditions in the central Pacific until, 15000 years ago, Nature, 449, 585-591, 2007.

Bradley, R. S., Vuille, M., Diaz, H. F., and Vergara, W.: Threats to water supplies in the Tropical Andes, Science, 312, 5781, 1755-1756, 2006.

15 Braithwaite, R. J.: Positive degree-day factors for ablation on the Greenland ice-sheet studied by energy balance modeling, J. Glaciol., 41, 153-160, 1995.

Caceres, B., Francou, B., Favier, V., Bontron, G., Tachker, P., Bucher, R., Taupin J. D., Vuille, M., Maisincho, L., Delachaux, F., Chazarin, J. P., Cadier, E., and Villacis, M.: Glacier 15, Antisana, Ecuador: its glaciology and relations to water resources, in: Climate Variability and Change - Hydrological Impacts, Proceedings of the Fifth FRIEND World Conference held at Havana, Cuba, November 2006, edited by: Demuth, S., Gustard, A., Planos, E., Scatena, F., and Servat, E., IAHS Publ. 308, 479-482, 2006.

Cauvy-Fraunié, S., Condom, T., Rabatel, A., Villacis, M., Jacobsen, D., and Dangles, O.: Technical Note: Glacial influence in tropical mountain hydrosystems evidenced by the diurnal cycle

2013

Corripio, J.: Snow surface albedo estimation using terrestrial photography, Int. J. Remote Sens., 25, 5705-5729, doi:10.1080/01431160410001709002, 2004.

On the interest of positive degree day models for mass balance modeling in

the inner tropics

L. Maisincho et al.

\section{Title Page}

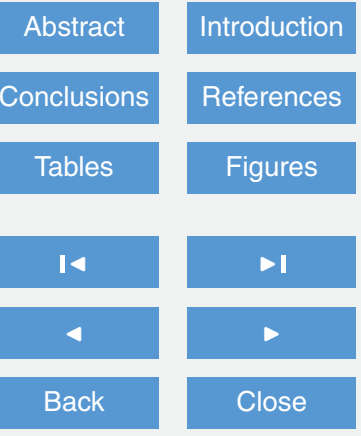

Full Screen / Esc

Printer-friendly Version

Interactive Discussion 
Favier, V., Wagnon, P., and Ribstein, P.: Glaciers of the outer and inner tropics: a different behavior but a common response to climatic forcing, Geophys. Res. Lett., 31, L16403, doi:10.1029/2004GL020654, 2004a.

Favier, V., Wagnon, P., Chazarin, J.-P., Maisincho, L., and Coudrain, A.: One-year measurements of surface heat budget on the ablation zone of Antizana glacier 15, Ecuadorian Andes, J. Geophys. Res., 109, D18105, doi:10.1029/2003JD004359, 2004b.

Favier, V., Coudrain, A., Cadier, E., Francou, B., Ayabaca, E., Maisincho, L., Praderio, E., Villacis, M., and Wagnon, P.: Evidence of groundwater flow on Antizana ice-covered volcano, Ecuador, Hydrolog. Sci. J., 53, 278-291, 2008.

10 Favier, V., Agosta, C., Genthon, C., Arnaud, L., Trouvillez, A., and Gallée, H.: Modeling the mass and surface heat budgets in a coastal blue ice area of Adelie Land, Antarctica, J. Geophys. Res., 116, F03017, doi:10.1029/2010JF001939, 2011.

Francou, B., Ribstein, P., Saravia, R., and Tiriau, E.: Monthly balance and water discharge of an inter-tropical glacier: Zongo Glacier, Cordillera Real, Bolivia, $16^{\circ} \mathrm{S}$, J. Glaciol., 41, 61-67, 1995.

Francou, B., Ramírez, E., Cáceres, B., and Mendoza, J.: Glacier evolution in the Tropical Andes during the last decades of the 20th century: Chacaltaya, Bolivia, and Antizana, Ecuador, Ambio, 29, 416-422, 2000.

Francou, B., Vuille, M., Favier, V., and Cáceres, B.: New evidence for an ENSO impact on low latitude glaciers: Antizana 15, Andes of Ecuador, $0^{\circ} 28^{\prime}$ S, J. Geophys. Res., 109, D18106, doi:10.1029/2003JD004484, 2004.

Hastenrath, S.: The Glaciation of the Ecuadorian Andes, Balkema, Rotterdam, the Netherlands, 173 pp., 1981.

Hastenrath, S. and Kruss, P. D.: The dramatic retreat of Mount Kenya's glaciers between 1963 and 1987: greenhouse forcing, Ann. Glaciol., 16, 127-133, 1992.

Hock, R.: Temperature index melt modelling in mountain areas, J. Hydrol., 282, 104-115, doi:10.1016/S0022-1694(03)00257-9, 2003.

Hostetler, S.W and Clark, P. U.: Tropical climate at the Last Glacial Maximum inferred from glacier mass-balance modeling, Science, 290, 1747-1750, 2000.

30 Huss, M. and Bauder, A.: 20th-century climate change inferred from four long-term point observations of seasonal mass balance, Ann. Glaciol., 50, 207-214, 2009.

Jomelli, V., Khodri, M., Favier, V., Brunstein, D., Ledru, M. P., Wagnon, P., Blard, P. H., Sicart, J. E., Braucher, R., Grancher, D., Bourlès, D., and Vuille, M.: Irregular tropical
On the interest of positive degree day models for mass balance modeling in

the inner tropics

L. Maisincho et al.

Title Page

Abstract

Introduction

Conclusions

References

Tables

Figures

14

$>$ I

4

Back

Close

Full Screen / Esc

Printer-friendly Version

Interactive Discussion 
glacier retreat over the Holocene driven by progressive warming, Nature, 474, 196-199, doi:10.1038/nature10150, 2011.

Jordan, E., Ungerechts, L., Caceres, B., Penafiel, A., and Francou, B.: Estimation by photogrammetry of the glacier recession on the Cotopaxi Volcano (Ecuador) between 1956 and

5 1997, Hydrolog. Sci. J., 50, 949-961, 2005.

Kalnay, E., Kanamitsu, M., Kistler, R., Collins, W., Deaven, D., Gandin, L., Iredell, M., Saha, S., White, G., Woollen, J., Zhu, Y., Leetmaa, A., Reynolds, R., Chelliah, M., Ebisuzaki, W., Higgins, W., Janowiak, J., Mo, K. C., Ropelewski, C., Wang, J., Roy, J., and Dennis, J.: The NCEP/NCAR 40-Year Reanalysis Project, B. Am. Meteorol. Soc., 77, 437-471, 1996.

10 Kaser, G.: Glacier-climate interaction at low-latitudes, J. Glaciol., 47, 195-204, 2001.

Kaser, G. and Osmaston, H. A.: Tropical Glaciers, Cambridge University Press, New York, 228 pp., 2002.

L'hote, Y., Chevallier, P., Coudrain, A., Lejeune, Y., and Etchevers, P.: Relationship between precipitation phase and air temperature: comparison between the Bolivian Andes and the Swiss Alps: glacier shrinkage in the Andes and consequences for water resources, Hydrolog. Sci. J., 50, 989-997, 2005.

Ohmura, A.: Physical basis for the temperature/melt-index method, J. Appl. Meteorol., 40, 753761, 2001.

Oke, T. R.: Boundary Layer Climates, 2nd Edn., Routledge, New York, 435 pp., 1987.

Pellicciotti, F., Brock, B., Strasser, U., Burlando, P., Funk, M, and Corripio, J.: An enhanced temperature-index glacier melt model including the shortwave radiation balance: development and testing for Haut Glacier d'Arolla, Switzerland, J. Glaciol., 51, 573-587, 2005.

Rabatel, A., Francou, B., Soruco, A., Gomez, J., Cáceres, B., Ceballos, J. L., Basantes, R., Vuille, M., Sicart, J.-E., Huggel, C., Scheel, M., Lejeune, Y., Arnaud, Y., Collet, M., Condom, T., Consoli, G., Favier, V., Jomelli, V., Galarraga, R., Ginot, P., Maisincho, L., Mendoza, J., Ménégoz, M., Ramirez, E., Ribstein, P., Suarez, W., Villacis, M., and Wagnon, P.: Current state of glaciers in the tropical Andes: a multi-century perspective on glacier evolution and climate change, The Cryosphere, 7, 81-102, doi:10.5194/tc-7-81-2013, 2013.

Radiæ, V. and Hock, R.: Regionally differentiated contribution of mountain glaciers and ice caps to future sea-level rise, Nat. Geosci., 4, 91-94, 2011.

Rojas, M.: Multiply nested regional climate simulation for southern South America: sensitivity to model resolution, Mon. Weather Rev., 134, 2208-2223, 2006.

On the interest of positive degree day models for mass balance modeling in the inner tropics

L. Maisincho et al.

Title Page

Abstract Introduction

Conclusions References

Tables Figures

14 4

Back

$\Delta$

$\triangleright$

Close

Full Screen / Esc

Printer-friendly Version

Interactive Discussion

2667 
Sicart, J.-E., Hock, R., and Six, D.: Glacier melt, air temperature, and energy balance in different climates: the Bolivian Tropics, the French Alps, and northern Sweden, J. Geophys. Res., 113, D24113, doi:10.1029/2008JD010406, 2008.

Urrutia, R. and Vuille, M.: Climate change projections for the tropical Andes using a regional climate model: temperature and precipitation simulations for the end of the 21st century, J. Geophys. Res., 114, D02108, doi:10.1029/2008JD011021, 2009.

Van den Broeke, M., Bus, C., Ettema, J., and Smeets, P.: Temperature thresholds for degree-day modeling of Greenland ice sheet melt rates, Geophys. Res. Lett., 37, L18501, doi:10.1029/2010GL044123, 2010.

10 Villacis, M.: Ressources en eau glaciaire dans les Andes d'Equateur en relation avec les variations du climat: le cas du volcan Antisana, Ph.D. thesis, Univ. Montpellier II, Montpellier, France, 231 pp., 2008.

Vuille, M. and Bradley, R. S.: Mean annual temperature trends and their vertical structure in the Tropical Andes, Geophys. Res. Lett., 27, 3885-3888, 2000.

Vuille, M., Bradley, R. S., and Keimig, F.: Climate variability in the Andes of Ecuador and its relation to Tropical Pacific and Atlantic Sea surface temperature anomalies, J. Climate, 13, 2520-2535, 2000.

Vuille, M., Francou, B., Wagnon, P., Juen, I., Kaser, G., Mark, B. G., and Bradley, R. S.: Climate change and tropical Andean glaciers: past, present and future, Earth-Sci. Rev., 89, 79-96, doi:10.1016/j.earscirev.2008.04.002, 2008.

Wagnon, P., Ribstein, P., Francou, B., and Pouyaud, B.: Annual cycle of energy balance of Zongo Glacier, Cordillera Real, Bolivia, J. Geophys. Res., 104, 3907-3923, 1999.

Wagnon, P., Lafaysse, M., Lejeune, Y., Maisinsho, L., Rojas, M., and Chazarin J. P.: Understanding and modelling the physical processes that govern the melting of the snow cover in a tropical mountain environment in Ecuador, J. Geophys. Res., 114, D19113, doi:10.1029/2009JD012292, 2009.

On the interest of positive degree day models for mass balance modeling in the inner tropics

L. Maisincho et al.

Title Page

Abstract Introduction

Conclusions References

Tables Figures

14

$\Delta$

4

Back

Close

Full Screen / Esc

Printer-friendly Version

Interactive Discussion 
Table 1. List of equipment: sensors and their specifications installed at $A W S_{G 1}$ station (for SEB calculations) and at $\mathrm{AWS}_{\mathrm{M}}$ at 4900 m a.s.I.), and thermometers at $\mathrm{AWS}_{\mathrm{G} 2}$ and at $\mathrm{HOBO}$ station (4785 m a.s.l.) and rain gauge characteristics (4550 m a.s.I.).

\begin{tabular}{|c|c|c|c|}
\hline Data measured at $A W S_{G 1}$ and $A W S_{M}^{1}$ & Type of sensor & Height $^{2}, \mathrm{~cm}$ & Accuracy according to the manufacturer \\
\hline Air temperature, ${ }^{\circ} \mathrm{C}$ & Vaisala HMP 45 , aspirated ${ }^{3}$ & 30 and 180 & $\pm 0.2^{\circ} \mathrm{C}$ \\
\hline Relative humidity, \% & Vaisala HMP 45 , aspirated ${ }^{3}$ & 30 and 180 & $\pm 2 \%$ \\
\hline Wind speed, $\mathrm{m} \mathrm{s}^{-1}$ & Young 05103 & 30 and 180 & $\pm 0.3 \mathrm{~ms}^{-1}$ \\
\hline Wind direction, deg & Young 05103 & 30 and 180 & $\pm 3^{\circ}$ \\
\hline Incident short-wave radiation, $\mathrm{W} \mathrm{m}^{-2}$ & Kipp\&Zonen CM3, $0.305<\lambda<2.8 \mu \mathrm{m}$ & 85 & $\pm 3 \%$ \\
\hline Reflected short-wave radiation, $\mathrm{Wm}^{-2}$ & Kipp\&Zonen CM3, $0.305<\lambda<2.8 \mu \mathrm{m}$ & 85 & $\pm 3 \%$ \\
\hline Incoming long-wave radiation, $\mathrm{Wm}^{-2}$ & Kipp\&Zonen CG3, $5<\lambda<50 \mu \mathrm{m}$ & 85 & $\pm 3 \%$ \\
\hline Outgoing long-wave radiation, $\mathrm{W} \mathrm{m}^{-2}$ & Kipp\&Zonen CG3, $5<\lambda<50 \mu \mathrm{m}$ & 85 & $\pm 3 \%$ \\
\hline Data measured at $\mathrm{AWS}_{\mathrm{G} 2}$ & Sensor Type & Elevation (ma.s.I.) & Characteristics and accuracy \\
\hline Air temperature, ${ }^{\circ} \mathrm{C}$ & Vaisala HMP 45 , aspirated ${ }^{3}$ & 4785 & $\pm 0.2^{\circ} \mathrm{C}$ \\
\hline Data measured at $\mathrm{HOBO}$ & Sensor Type & Elevation (m a.s.I.) & Characteristics and accuracy \\
\hline Air temperature, ${ }^{\circ} \mathrm{C}$ Daily precipitation, $\mathrm{mm}$ & Automatic HoboPro Automatic Hobo Rain Gauge ${ }^{4}$ & 47854785 and 4550 & $\pm 0.2^{\circ} \mathrm{C}$, Opening: $200 \mathrm{~cm}^{2}$, Height: $100 \mathrm{~cm}$ \\
\hline
\end{tabular}

${ }_{1}^{1}$ Quantities are half-hourly means of measurements made at $15 \mathrm{~s} \mathrm{time-intervals} \mathrm{except} \mathrm{for} \mathrm{wind} \mathrm{direction,} \mathrm{which} \mathrm{are} \mathrm{instantaneous} \mathrm{values} \mathrm{measured} \mathrm{every} 30$ min.

${ }^{2}$ Heights are variable but known with reasonable accuracy thanks to manual measurements made every 10 days.

${ }^{3}$ To prevent measurement errors due to radiation, Vaisala hygro-thermometers were adequately shielded and artificially ventilated.

${ }^{4}$ Tipping bucket recording rain gauge, measured precipitation $0.214 \mathrm{~mm}$.

On the interest of positive degree day

models for mass

balance modeling in the inner tropics

L. Maisincho et al.

Title Page

Abstract

Conclusions

Tables

14

4

Back

Full Screen / Esc

Printer-friendly Version

Interactive Discussion 
Table 2. Description of temperature data used and correlations with Antizana data at 4900 m a.s.l.

\begin{tabular}{|c|c|c|c|c|}
\hline & $\mathrm{AWS}_{\mathrm{G} 1}$ & $\mathrm{AWS}_{\mathrm{G} 2}$ & $\mathrm{AWS}_{\mathrm{M}}$ & $\mathrm{HOBO}$ \\
\hline Elevation (m a.s.I.) & 4900 & 4900 and $5000^{1}$ & 4875 & 4875 \\
\hline Location & Glacier & Glacier & Moraine & Moraine \\
\hline Type of sensor & Vaisala HMP45 & Vaisala HMP45 & Vaisala HMP45 & HOBOPro \\
\hline $\begin{array}{l}\text { Used as reference temperature during } \\
\text { the following period }\end{array}$ & 2000-2004 & 2005 and $2007-2008$ & 2006 & \\
\hline Data gap during each period ${ }^{2}$ & $\begin{array}{l}\text { 2000-2001: } 41 \% \\
\text { 2002-2004: } 14 \%\end{array}$ & $\begin{array}{l}2005 \text { and 2007-2008: } 21 \%: \\
\text { 2005-2008: } 8 \%\end{array}$ & 2006: $13 \%$ & 2000-2008: $13 \%$ \\
\hline $\begin{array}{l}\text { Determination coefficient }\left(r^{2}\right) \\
\text { with } \mathrm{AWS}_{\mathrm{G} 1} \text { during each period }\end{array}$ & & 0.85 and 0.92 (2003 and 2004) & & $0.80(2002-2004)$ \\
\hline $\begin{array}{l}\text { Determination coefficient }\left(r^{2}\right) \\
\text { with } \mathrm{AWS}_{\mathrm{G} 2} \text { during each period }\end{array}$ & 0.85 and 0.92 (2003 and 2004) & & 0.87 and 0.89 (2005 and 2008) & $0.86(2007-2008)$ \\
\hline $\begin{array}{l}\text { Determination coefficient }\left(r^{2}\right) \\
\text { with HOBO during each period }{ }^{3}\end{array}$ & $0.80(2002-2004)$ & $0.86(2007-2008)$ & $0.89(2005-2008)$ & \\
\hline
\end{tabular}

\footnotetext{
${ }^{1} \mathrm{AWS}_{\mathrm{G} 2}$ is a displaceable station, and was located at $5000 \mathrm{~m}$ a.s.l. between January-February and June-December 2003.

${ }^{2}$ Number of days with missing data gap (in percent).
NWS
}

${ }^{3}$ Periods are in parentheses.

On the interest of positive degree day models for mass balance modeling in the inner tropics

L. Maisincho et al.

\section{Title Page}

\section{Abstract}

Conclusions

Tables

14

Back

Full Screen / Esc

Printer-friendly Version

Interactive Discussion 
Table 3. Data used in this study.

\begin{tabular}{|c|c|c|c|}
\hline Data & Model & Input data for modeling & Model validation \\
\hline Air temperature & PDD & $\begin{array}{l}\text { 2000-2008: Antizana, }(4875,4900 \text { and } 5000 \mathrm{~m} \text { a.s.l. }) \\
\text { 2000-2008: Izobamba }(3050 \mathrm{~m} \text { a.s.I.) } \\
\text { 2000-2008: NCEP1 ( } 570 \mathrm{hPa})\end{array}$ & Mass balance and Melting boxes \\
\hline Precipitation & PDD & $\begin{array}{l}\text { 2000-2008: Antizana, }(4550 \mathrm{~m} \text { a.s.l.) } \\
\text { 2000-2008: Izobamba }(3050 \mathrm{~m} \text { a.s.I.) } \\
\text { 2000-2008: NCEP1 ( } 500 \mathrm{hPa})\end{array}$ & Mass balance and Melting boxes \\
\hline $\begin{array}{l}\text { Mass balance and ELA } \\
\text { measurements }\end{array}$ & PDD for ELA modeling & $\begin{array}{l}\text { 1964-2008: Izobamba ( } 3050 \mathrm{~m} \text { a.s.I.) } 1950-1963: \text { NCEP1 ( } 500 \mathrm{hPa}) \\
\text { 2000-2008: Antizana, (from } 4850 \text { to } 5700 \mathrm{~m} \text { a.s.I.) }\end{array}$ & Terrestrial photos \\
\hline Calculated melting & SEB ${ }^{*}$ & 14 Mar 2002-31 Mar 2003: Antizana, (4900 m a.s.I.) & Melting boxes \\
\hline Measured melting & & 12 Mar 2002-11 Jun 2013 (43 days): Antizana, (4900 m a.s.I.) & \\
\hline Terrestrial photographs & & 2004-2008: Antizana, 712 daily photos, (4875 m a.s.I.) & \\
\hline Annual air temperature & & 1950-1985: NCEP1 (570 hPa) & \\
\hline Monthly historical temperature & & 1950-1985: Quito, Quito station, (2820 m a.s.I.) & \\
\hline
\end{tabular}

* Surface energy balance data.

\section{TCD}

8, 2637-2684, 2014

On the interest of positive degree day

models for mass balance modeling in the inner tropics

L. Maisincho et al.

\section{Title Page}

Abstract

Introduction

Conclusions

References

Tables

Figures

14

$>1$

Back

Close

Full Screen / Esc

Printer-friendly Version

Interactive Discussion 
Table 4. Temporal variation of precipitation ratio between NCEP1 data and Izobamba.

\begin{tabular}{lrrrrr}
\hline & $\begin{array}{c}\text { Period I } \\
1964-1976\end{array}$ & $\begin{array}{r}\text { Period II } \\
1977-1999\end{array}$ & $\begin{array}{r}\text { Period II' } \\
1977-2008\end{array}$ & $\begin{array}{r}\text { Period III } \\
2000-2008\end{array}$ & $\begin{array}{r}\text { Total Period } \\
1964-2008\end{array}$ \\
\hline Total number of years & 13 & 23 & 35 & 9 & 45 \\
Ratio $P_{\text {Izobamba }} / P_{\text {NCEP1 }}$ & $110 \%$ & $80 \%$ & $75 \%$ & $67 \%$ & $83 \%$ \\
\hline
\end{tabular}

On the interest of positive degree day models for mass balance modeling in the inner tropics

L. Maisincho et al.

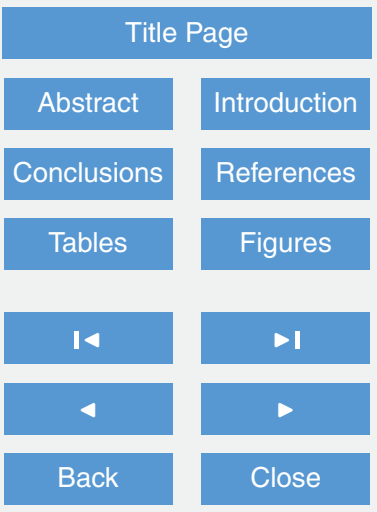

Full Screen / Esc

Printer-friendly Version

Interactive Discussion 
Table 5. Model sensitivity tests. Values (in percent) are the ratio of the "original" to the sensitivity test mass balance for the 2000-2008 period. Here, the "original" mass balance computed referred to is the mass balance obtained with optimized parameters, and sensitivity test mass balance results from computations with the parameter value given in the same cell. Values in parentheses are the standard deviation of the differences between annual original mass balance and the sensitivity test mass balance.

\begin{tabular}{rr|rr|rr|rr}
\hline $\begin{array}{r}\text { Value } \\
\left({ }^{\circ} \mathrm{C}\right)\end{array}$ & $\begin{array}{c}T_{\text {Threshold }} \\
\text { difference }\end{array}$ & $\begin{array}{c}F_{\text {ice }} \\
\text { Value }\end{array}$ & difference & $\begin{array}{r}F_{\text {snow }} \\
\text { Value } \\
\left(\mathrm{mm} . \text { w.e. } \mathrm{K}^{-1} \mathrm{~d}^{-1}\right)\end{array}$ & & difference & $\begin{array}{c}\text { Lapse Rate } \\
\text { Value } \\
\left(\mathrm{mm} . \text { w.e. } \mathrm{K}^{-1} \mathrm{~d}^{-1}\right)\end{array}$ \\
\hline 0 & $320 \%(346 \%)$ & 11 & $134 \%(131 \%)$ & 5.5 & $-25 \%(29 \%)$ & -9 & $22 \%(22 \%)$ \\
-1 & $186 \%(207 \%)$ & 9.8 & $-98 \%(96 \%)$ & 4.9 & $0 \%(0 \%)$ & -8 & $0 \%(0 \%)$ \\
-1.9 & $0 \%(0 \%)$ & 6.5 & $0 \%(0 \%)$ & 4 & $37 \%(43 \%)$ & -7 & $-28 \%(27 \%)$ \\
-2.5 & $159 \%(181 \%)$ & 5.5 & $329 \%(354 \%)$ & 3.5 & $58 \%(67 \%)$ & -6 & $-67 \%(66 \%)$ \\
\hline
\end{tabular}

On the interest of positive degree day

models for mass

balance modeling in the inner tropics

L. Maisincho et al.

Title Page

Abstract

Conclusions

Tables

14

4

Back

Introduction

References

Figures

DI

$\triangleright$

Close

Full Screen / Esc

Printer-friendly Version

Interactive Discussion 


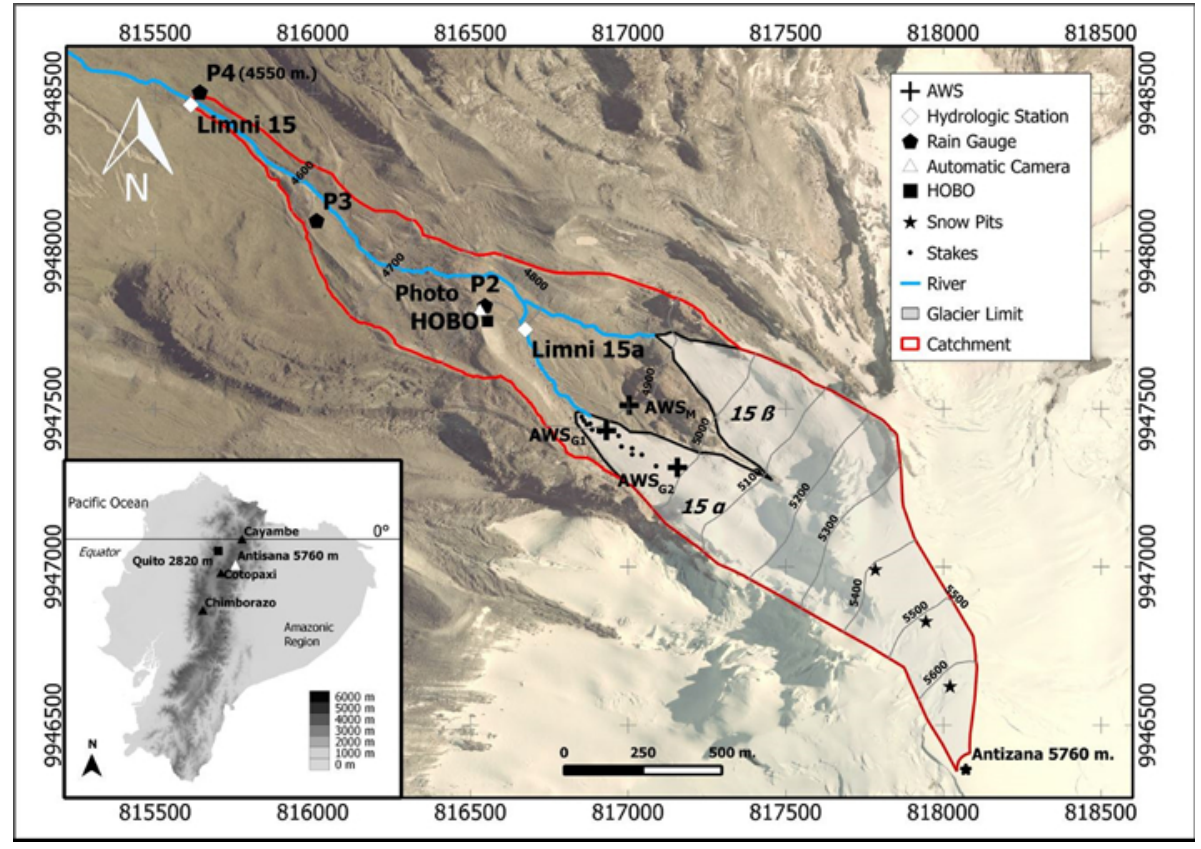

Figure 1. Orientation map of Antizana Glacier 15 showing location of monitoring equipment. Projection is on UTM zone 17, coordinate system is WGS84. Inset shows a physical map of Ecuador. In this figure, $A W S_{\mathrm{G} 2}$ refers to the location of the AWS in 2003; during the remaining periods the station was located a few meters away from $A_{W} S_{G 1}$ or on Glacier 12 (in 2006). The background image is an orthoimage of Antizana Volcano taken in 2010 by the Instituto Geográfico Militar of Ecuador: http://www.geoportaligm.gob.ec/portal/index.php/catalogo-de-datos/.

\section{TCD}

8, 2637-2684, 2014

On the interest of positive degree day

models for mass

balance modeling in

the inner tropics

L. Maisincho et al.

Title Page
Abstract

Conclusions

Tables

14

4

Back
Introduction

References

\section{Figures}

$\Delta$ I

\section{Full Screen / Esc}

Printer-friendly Version

Interactive Discussion 


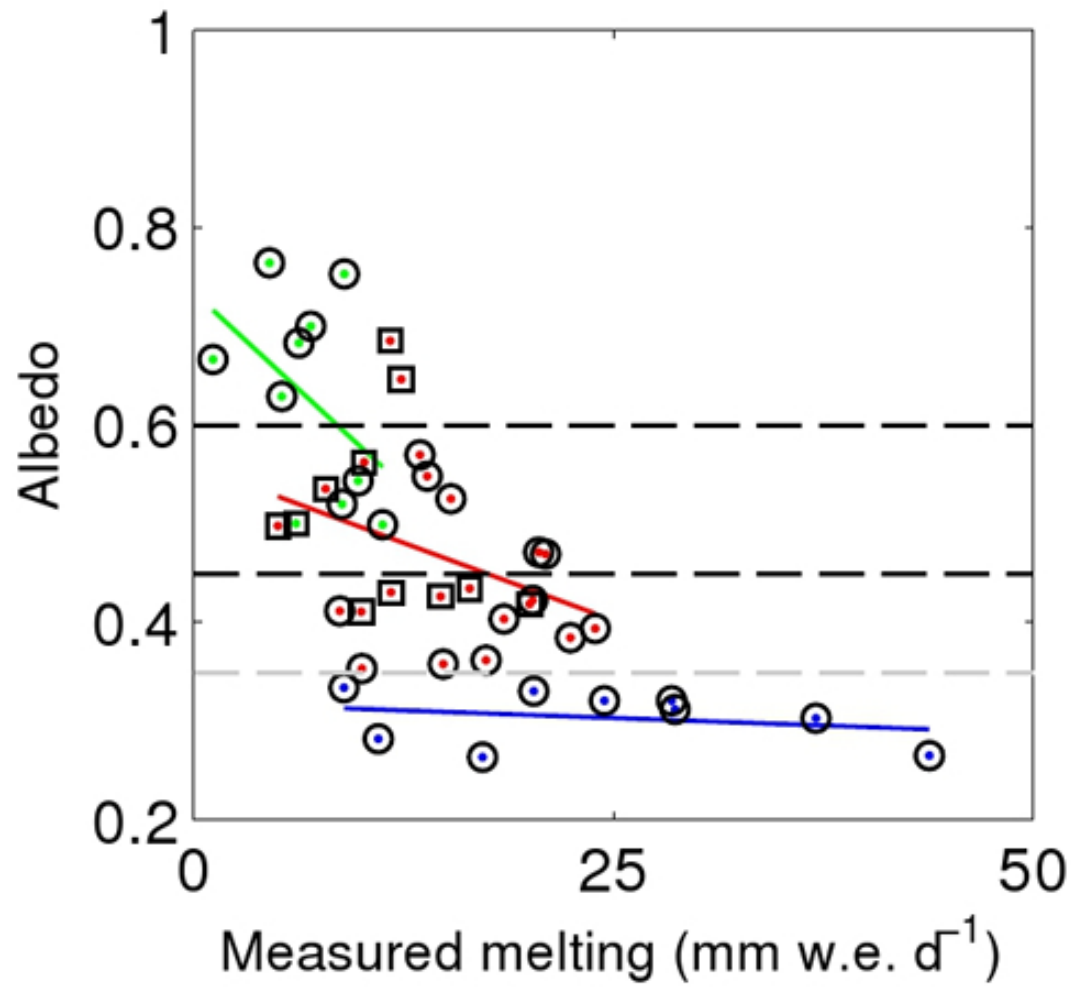

Figure 2. Comparison between measured melting rates in melt boxes and mean daily albedo for snow (green), clean ice (red) and dirty ice (blue). Circles represent Period 1 (windy period) and squares Period 2. Dashed horizontal black lines are optimized thresholds between snow, and clean and dirty ice. The dashed gray line is the original albedo threshold between dirty and clean ice surfaces assessed in field observations. The color code used for the curves is the same as that used for the circles.

\section{TCD}

8, 2637-2684, 2014

On the interest of positive degree day

models for mass

balance modeling in

the inner tropics

L. Maisincho et al.

Title Page

Abstract

Conclusions

Tables

14

Back

Full Screen / Esc

Printer-friendly Version

Interactive Discussion 

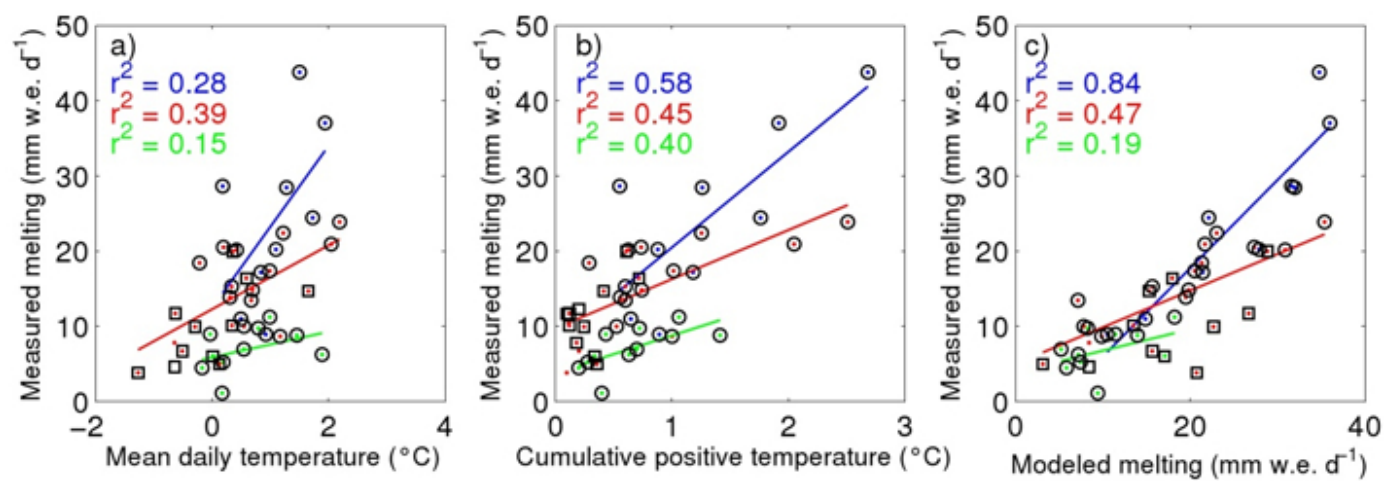

Figure 3. Comparison between daily melting rates in melting boxes with (a) mean daily temperature values; (b) the cumulative hourly positive temperature values at a daily time step; and (c) modeled melting amounts from SEB quantification. Circles represent values for snow (green), clean ice (red) and dirty ice (blue). Circles refer to Period 1 (windy period) and squares to Period 2. The color code of the curves is the same as that used for the circles.

On the interest of positive degree day models for mass balance modeling in the inner tropics

L. Maisincho et al.

\section{Title Page}

\section{Abstract}

Conclusions

Tables

14

Back
Introduction

References

Figures

DI

Close

Full Screen / Esc

Printer-friendly Version

Interactive Discussion 

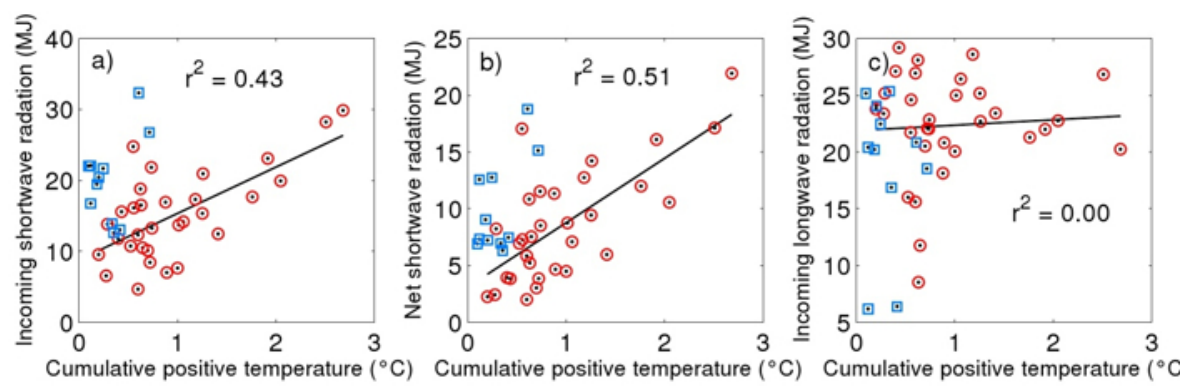

\section{$8,2637-2684,2014$
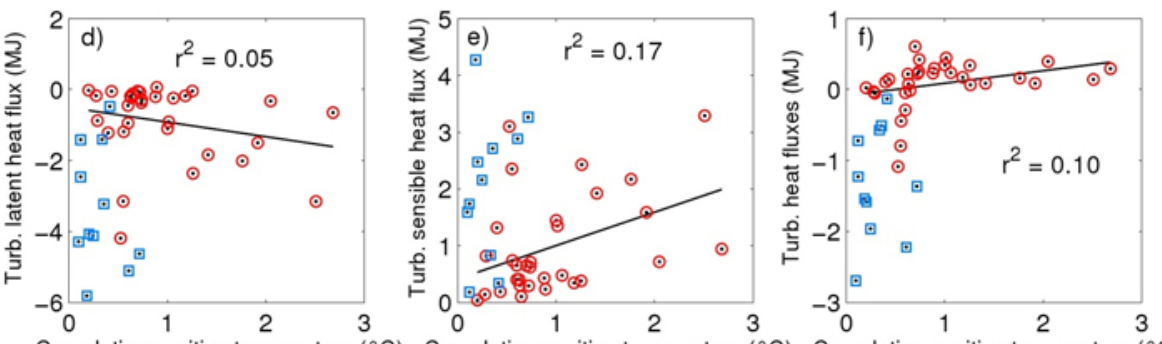

Cumulative positive temperature $\left({ }^{\circ} \mathrm{C}\right)$ Cumulative positive temperature $\left({ }^{\circ} \mathrm{C}\right)$ Cumulative positive temperature $\left({ }^{\circ} \mathrm{C}\right)$

Figure 4. Comparison between the cumulative hourly positive temperature values in the melting box experiments and (a) incoming shortwave radiation, (b) net shortwave radiation, (c) incoming longwave radiation, (d) turbulent latent heat flux, (e) turbulent sensible heat flux, and (f) turbulent heat fluxes $(\mathrm{LE}+H)$. Blue squares refer to Period 1 (windy period) and red circles refer to Period 2. The determination coefficients correspond to data for Period 2 only.

On the interest of positive degree day

models for mass

balance modeling in the inner tropics

L. Maisincho et al.

\section{Title Page}

\section{Abstract}

Conclusions

Tables

14

Back
Introduction

References

\section{Figures}

$>1$

Close

Full Screen / Esc

Printer-friendly Version

Interactive Discussion 

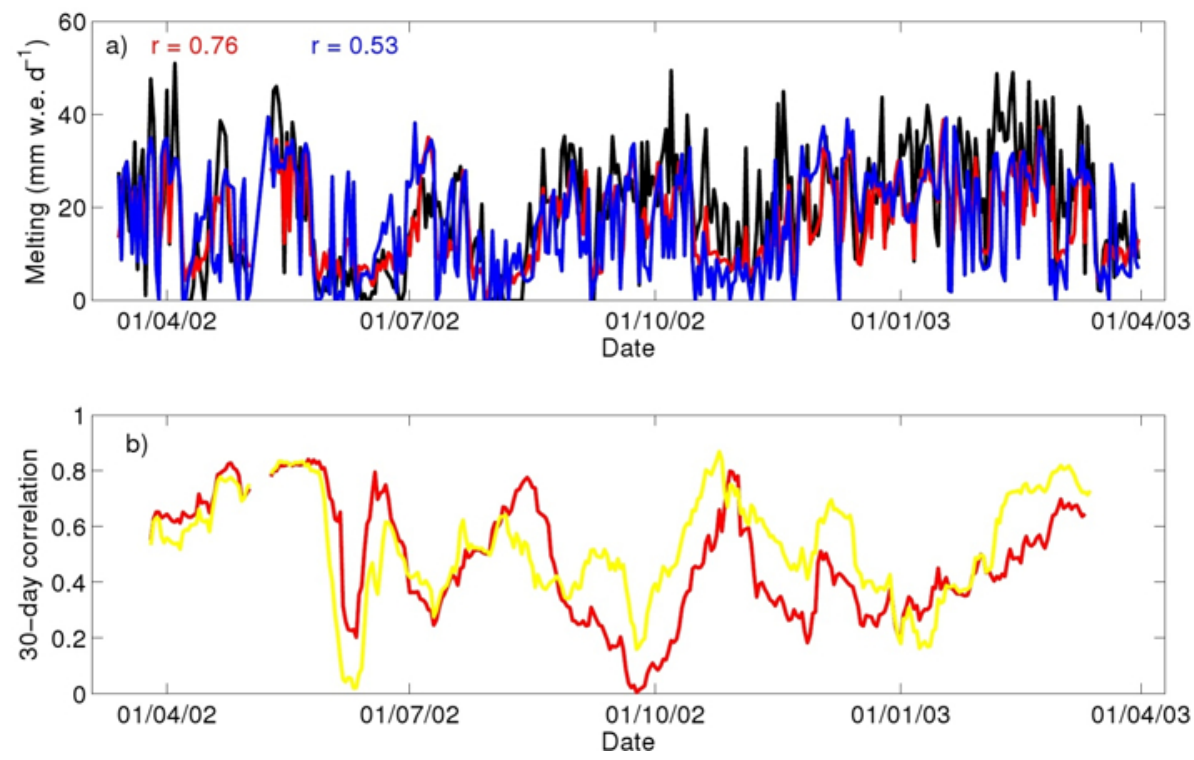

Figure 5. (a) Comparison between the computed melting rates obtained with the SEB model (black) and with the PDD model. The blue curve [resp. red] shows the results obtained using our initial guess [optimized] albedo thresholds, between dirty and clean ice $(0.35)$ [0.45] and between clean ice and snow (0.6) [0.6]. Ablation is presented assuming that melting begins when the daily temperature exceeds $T_{\text {threshold }}=-1.9^{\circ} \mathrm{C}$. (b) 30 day moving correlation between mean daily temperature and net shortwave radiation (yellow), and between melting amount obtained with the SEB model and with the PDD model (red). In Fig. 5a, the color of correlation coefficients correspond to the color of the curves.

\section{TCD}

8, 2637-2684, 2014

On the interest of positive degree day

models for mass

balance modeling in

the inner tropics

L. Maisincho et al.

\section{Title Page}

Abstract

Conclusions

Tables

14

4

Back
Introduction

References

\section{Figures}

$\Delta 1$

$\triangleright$

Close
Full Screen / Esc

Printer-friendly Version

Interactive Discussion 


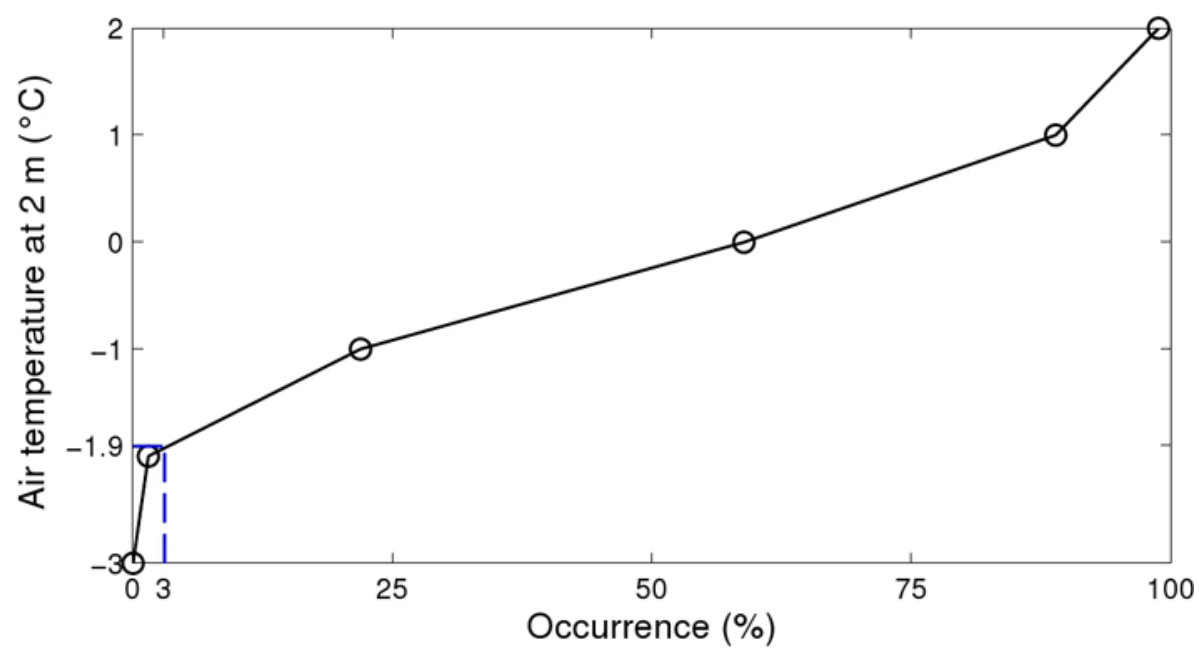

Figure 6. Cumulative occurrence of melting amounts in 2002-2003, according to daily mean air temperature at a height of $2 \mathrm{~m}$ above the glacier surface. The dashed blue line shows that $3 \%$ of the melting amount events occurred at a mean daily temperature below $-1.9^{\circ} \mathrm{C}$.

\section{TCD}

$8,2637-2684,2014$

On the interest of positive degree day models for mass balance modeling in the inner tropics

L. Maisincho et al.

Title Page
Abstract

Conclusions

Tables

14

Back
Introduction

References

Figures

DI

\section{Full Screen / Esc}

Printer-friendly Version

Interactive Discussion 

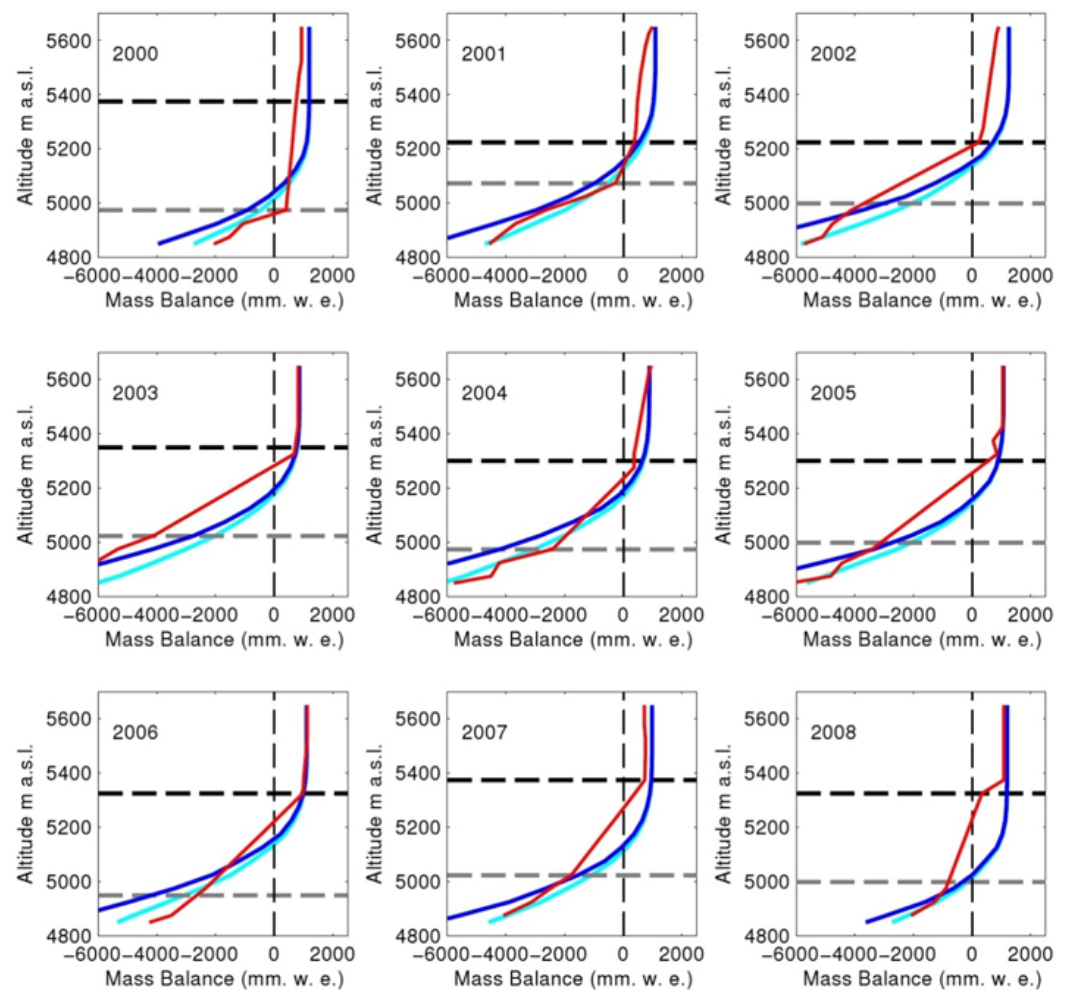

\section{8, 2637-2684, 2014}

On the interest of positive degree day

models for mass

balance modeling in

the inner tropics

L. Maisincho et al.

\section{Title Page}

\section{Abstract}

Conclusions

Tables

14

Back

Introduction

References

\section{Figures}

$\Delta$ I

$\triangleright$

\section{Full Screen / Esc}

Printer-friendly Version

Interactive Discussion 


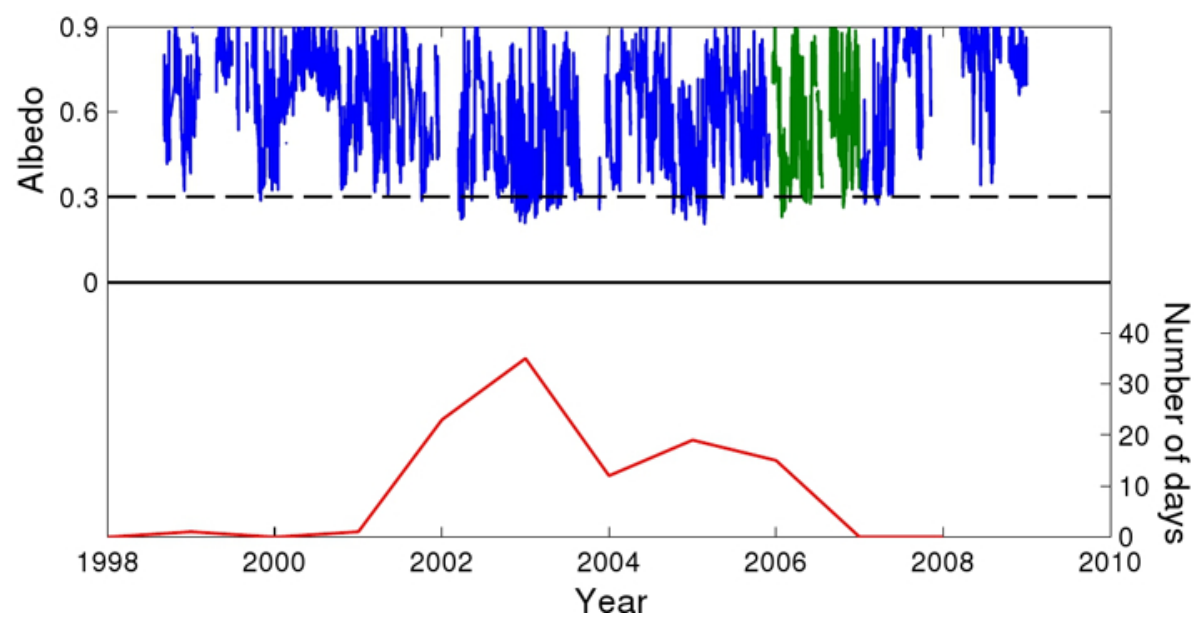

Figure 8. Daily albedo (upper panel) at $4900 \mathrm{~m}$ a.s.l. on Antizana Glacier 15 (from 1999 to 2005 and in 2008 , in blue) and at 4770 m a.s.I. on Antizana Glacier 12 (2006, green). The red line shows the number of days with albedo values below 0.3 (lower panel). Note that no data were available between 17 December 2001 and 14 March 2002.
TCD

$8,2637-2684,2014$

On the interest of positive degree day

models for mass

balance modeling in the inner tropics

L. Maisincho et al.

Title Page
Abstract

Conclusions

Tables

14

Back
Introduction

References

Figures

DI

\section{Close}

Full Screen / Esc

Printer-friendly Version

Interactive Discussion 

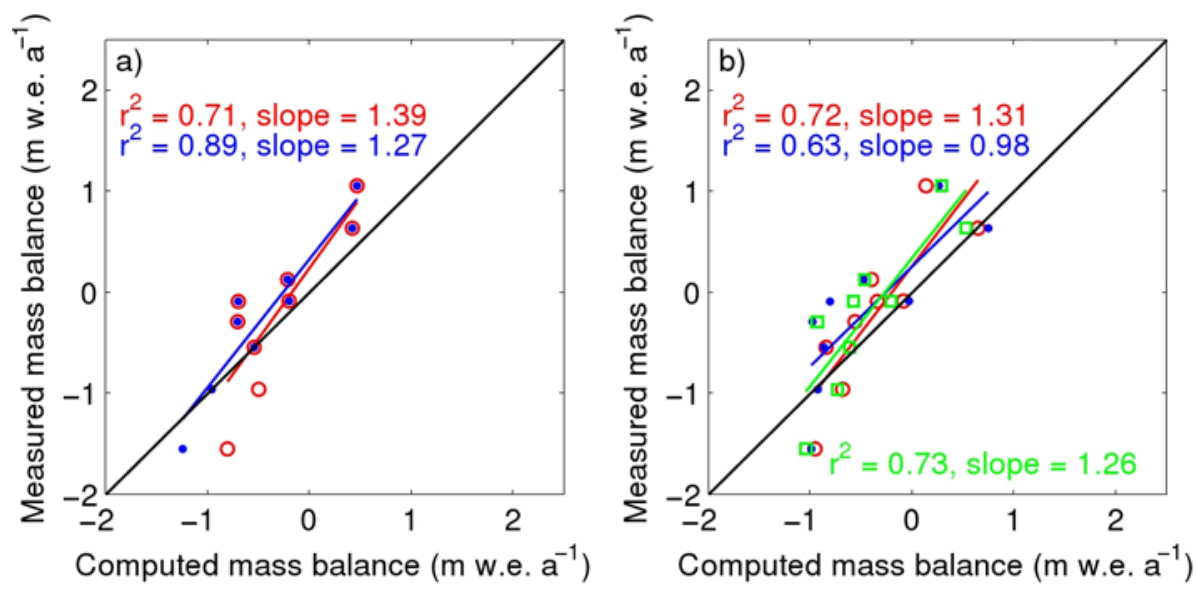

Figure 9. Comparison between the computed and the measured glacier-wide annual mass balance of Antizana Glacier 15. (a) Modeled data are forced with temperature and precipitation data from Glacier Antizana 15 catchment. Red circles indicate the results using the DDF for clean ice only, and the blue circles the results when combining the $F_{\text {clean_ice }}$ or $F_{\text {ice }}$ (for 2002 and 2003), or (b) with temperature from Izobamba station and precipitation from Antizana (red circles), with temperature and precipitation data from Izobamba (blue circles), and with data from NCEP1 reanalyses (green squares). The colors of the determination coefficient and slope values correspond to the colors of the symbols. The $1: 1$ line is also shown in black.

\section{TCD}

$8,2637-2684,2014$

On the interest of positive degree day

models for mass

balance modeling in

the inner tropics

L. Maisincho et al.

Title Page

Abstract

Introduction

Conclusions

References

Tables

Figures

14

$\Delta 1$

4

Back

Close

Printer-friendly Version

Interactive Discussion 


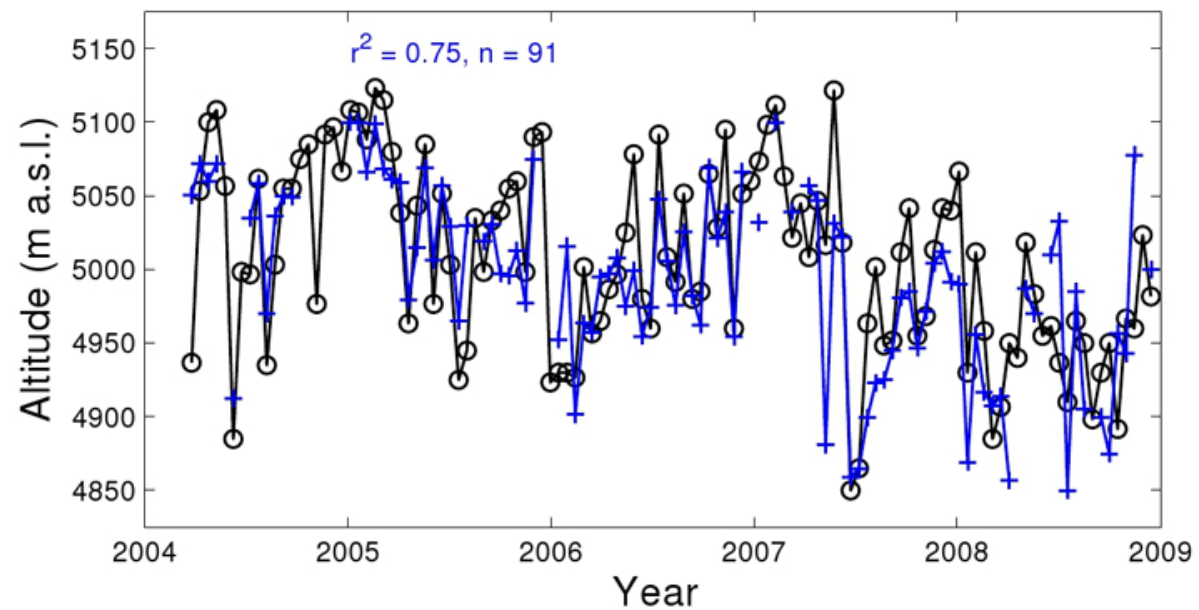

Figure 10. Comparison between variations in the observed 15 day average snowline elevation (blue) and the modeled 15 day average snowline elevation (black), over the period 2004-2008.

\section{TCD}

\section{8, 2637-2684, 2014}

On the interest of positive degree day models for mass balance modeling in the inner tropics

L. Maisincho et al.

Title Page

\section{Abstract}

Conclusions

Tables

14

Back
Introduction

References

Figures
Full Screen / Esc

Printer-friendly Version

Interactive Discussion 

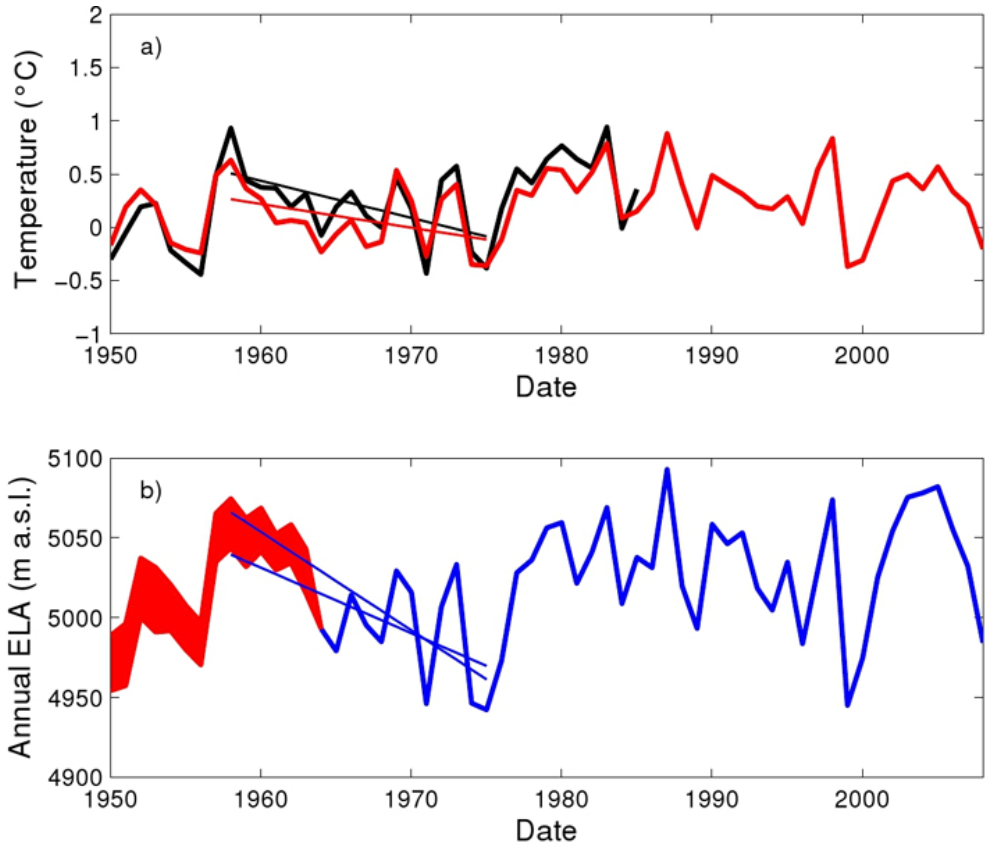

Figure 11. (a) Temporal variations of the annual average air temperature at Quito (black) and from reanalysis data at $\left(77^{\circ} \mathrm{W} ; 0.2^{\circ} \mathrm{S}\right)$ for the $700 \mathrm{hPa}$ level (red). The temperature at Quito was shifted by $-13.3^{\circ} \mathrm{C}$, to compare variations with those of Reanalyzed data. The narrow lines are regression lines for the 1958-1976 period. (b) Temporal variations in the modeled ELA using Izobamba precipitation from 1964 to 2008 (blue) and the corrected reanalyzed precipitation (red) before 1964, which were corrected precipitation according to two possible ratios (see Sect. 3.3.1). The width of the red curve represents the uncertainty in the two scenarios. PDD modeling was performed using the reanalyzed temperature.

On the interest of positive degree day

models for mass

balance modeling in the inner tropics

L. Maisincho et al.

\section{Title Page}

\section{Abstract}

Conclusions

Tables

14

Back
Introduction

References

\section{Figures}

$>1$

$\rightarrow$

Close

Full Screen / Esc

Printer-friendly Version

Interactive Discussion 